TATIANI AYAKO GOTO DONATO

\title{
ESTUDO DA INFLUÊNCIA DO FATOR DE TRANSFORMAÇÃO DE CRESCIMENTO - BETA 1 (TGF- $\beta 1)$ EM CULTURA DE CÉLULAS OSTEOGÊNICAS INDUZIDAS COM FATORES MINERALIZANTES
}

Dissertação apresentada ao Instituto de Ciências Biomédicas da Universidade de São Paulo, para obtenção do título de Mestre em Ciências (Biologia Celular e Tecidual).

São Paulo 2009 


\section{ESTUDO DA INFLUÊNCIA DO FATOR DE TRANSFORMAÇÃO DE CRESCIMENTO - BETA 1 (TGF- $\beta 1$ ) EM CULTURA DE CÉLULAS OSTEOGÊNICAS INDUZIDAS COM FATORES MINERALIZANTES}

Dissertação apresentada ao Instituto de Ciências Biomédicas da Universidade de São Paulo, para obtenção do título de Mestre em Ciências.

Área de Concentração

Biologia Celular e Tecidual

Orientador

Prof. Dr. Victor Elias Arana-Chavez

São Paulo

2009 
DADOS DE CATALOGAÇÃO NA PUBLICAÇÃO (CIP)

Serviço de Biblioteca e Informação Biomédica do

Instituto de Ciências Biomédicas da Universidade de São Paulo

(C) reprodução total

Donato, Tatiani Ayako Goto.

Estudo da influência do TGF- $\beta 1$ em cultura de células osteogênicas induzidas por fatores mineralizantes / Tatiani Ayako Goto Donato. São Paulo, 2009.

Orientador: Victor Elias Arana-Chavez.

Dissertação (Mestrado) - Universidade de São Paulo. Instituto de Ciências Biomédicas. Departamento de Biologia Celular e do

Desenvolvimento. Área de concentração: Biologia Celular e Tecidual. Linha de pesquisa: Biologia oral.

Versão do título para o inglês: Study of the influence of TGF- $\beta 1$ in osteogenic cell culture induced by mineralizing factors.

Descritores: 1 . TGF- $\beta 1$ 2. Dexametasona 3 3. Células osteoprogenitoras 4. Mineralização I. Arana-Chavez, Victor Elias II. Universidade de São Paulo. Instituto de Ciências Biomédicas.

Programa de Pós Graduação em Biologia Celular e Tecidual III. Título. 
Candidato(a):

Título da Dissertação:

Orientador(a):
Tatiani Ayako Goto Donato.

Estudo da influência do TGF- $\beta 1$ em cultura de células osteogênicas induzidas por fatores mineralizantes.

Victor Elias Arana-Chavez.

A Comissão Julgadora dos trabalhos de Defesa da Dissertação de Mestrado, em sessão pública realizada a ....................................,
( ) Aprovado(a)
( ) Reprovado(a)

Examinador(a): Assinatura:

Nome:

Instituição:

Examinador(a): Assinatura:

Nome:

Instituição:

Presidente: Assinatura:

Nome:

Instituição: 


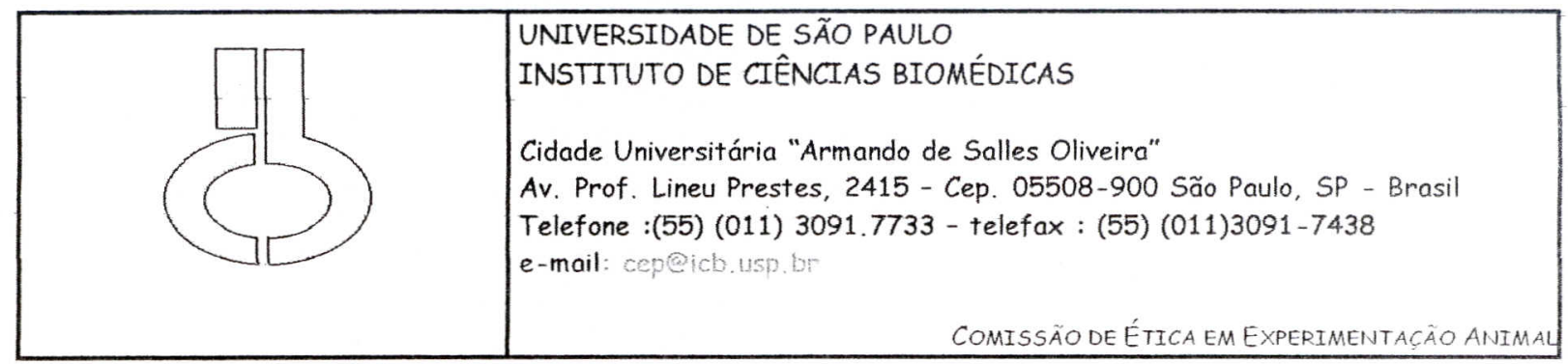

Decl. CEEA.013/07

DECLARAÇ $\tilde{A} O$

Em adendo ao Certificado 86/05/CEEA, aprovo a inclusão da aluna: TATIANI AYAKO GOTO DONATO ao protocolo intitulado: "Estudo imunocitoquímico de proteínas da matriz em cultura de fibroblastos de polpa dentária e gengiva humanas e osteoblastos de calvária de rato induzidos com fatores mineralizantes", para uso da espécie animal utilizado e métodos semelhantes, mediante solicitação do Prof. Dr. Victor Elias Arana-Chavez, responsável pela linha de Pesquisa.

São Paulo, 20 de abril de 2007.

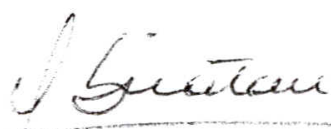

Prof. Dr. UBIRATAN FABRES MACHADO

Coordenador da CEEA- ICB/USP 
Aos meus pais, José Maria e Nanami, pelo exemplo, presença e apoio constante em todos os momentos da minha vida; por anularem seus sonhos e buscarem comigo os meus; por me darem as armas necessárias para que sozinha alcançasse honestamente todos os meus objetivos. $\mathcal{E}$ mesmo nem sempre entendo os porquês, por sempre confiarem e torcerem por mim.

A minha irmã Daiani, companheira e amiga, pela constante torcida.

Ao meu esposo, eterno namorado e melhor amigo, Marcus, pelo amor, carinho, compreensão, cumplicidade, incentivo constante e principalmente pela longa espera. Te amo!

A vocês, amores da minha vida, dedico este trabalho... 
AGRADECIMENTOS 
Em especial ao Prof. Dr. Victor Elias Arana-Chavez, orientador deste trabalho, pela amizade, oportunidade, ensinamentos e principalmente pelo exemplo de determinação, dedicação, serenidade e amor a docência das ciências.

Ao Prof. Dr. Carlos Roberto Grandini, da UNESP/Bauru, pela oportunidade de conhecer a vida científica durante a graduação, pelo incentivo à pós graduação e pela amizade.

Às Profas. Dra. Alison Colquhoun, Dra. Patrícia Gama e Dra. Cecília Helena Azevedo Gouveia Ferreira, pelas críticas e sugestões feitas na qualificação deste trabalho.

À todos os docentes do departamento de Biologia Celular e do Desenvolvimento pela dedicação, disponibilidade e ensinamentos.

Aos docentes responsáveis pelas salas multiusuários, por disponibilizarem os equipamentos para a realização dos experimentos.

Ao Prof. Dr. Paulo Tambasco Oliviera e a minha amiga de laboratório Elizabeth, por terem ensinado criteriosamente a técnica de obtenção das células osteogênicas.

Aos meus amigos e colegas do Laboratório de Biologia dos Tecidos Mineralizados, Bethinha, Dani, Na, Viva, Fê Yamamoto, Lorraine, Eloíza, Tais, Karla com K, Fábiooo, Felipe, Márcio (Baiano), Newton e Lu Massa, pelos momentos tensos que foram vividos na mesma bancada, por cada lágrima derramada, por cada sorriso que vinha seguido de uma boa gargalhada, pelos momentos de descontração tomando um bom café ou apreciando um castigo sempre bem servido; enfim, por todos os momentos que passamos juntos e que amenizaram a saudades que senti de casa.

Em especial as minhas amigas de laboratório que estiveram comigo durante todo o meu mestrado: Natasha e Daniela, pela sinceridade, honestidade, carinho e 
principalmente pela constante amizade; Viva, pela amizade e sobre tudo pelo exemplo de determinação e dedicação às ciências.

Aos meus colegas e amigos do Departamento de Biologia Celular e do Desenvolvimento, em especial a Marina, Kelly, Ana Zen, Alex, Cesar, Raquel, Juliano, Renato, Evandro e Jonatas, pela troca de experiências científicas e pelos vários momentos agradáveis de descontração.

Às minhas amigas de graduação que sempre se fizeram presente mesmo longe, Maira, Renatinha, Alexssandra, Milena, Carla e em especial a Mara.

Aos técnicos de Laboratório Leandro, Priscila, Marley, Cleusa, Emilia, Nancy, Raphael e em especial a Fernanda Barrence, por toda ajuda, sinceridade e amizade.

As secretárias do departamento de Biologia Celular e do Desenvolvimento, em especial a Celiana, secretária do Programa de Pós Graduação, pela atenção e cooperação constante.

Ao Gaspar e Edson, técnicos do setor de microscopia eletrônica, pela responsabilidade, eficiência e pelo capricho do trabalho desenvolvido.

Aos demais funcionários do Departamento de Biologia Celular e do Desenvolvimento, pelo auxílio e disponibilidade.

À Renaide, bioterista do Biotério Central ICB/USP, por disponibilizar os ratos wistar neonatos para realização deste trabalho.

À CNPq pelo financiamento.

E a todos que direta ou indiretamente, contribuíram na realização deste trabalho. 
$\mathcal{N a ̃ o ~ s e i ~ c o m o ~ p a r e c ̧ o ~ p a r a ~ o ~ m u n d o , ~ m a s ~ p a r a ~ m i m ~ e u ~}$ pareço ter sido apenas um menino brincando a beiramar, me divertindo enquanto encontrava aqui e ali um seixo mais liso ou uma concha mais bonita que as outras, enquanto o grande oceano da verdade estendia-se totalmente desconhecido diante de mim. 


\section{RESUMO}

DONATO, T.A.G. Estudo da influência do TGF- $\beta 1$ em cultura de células osteogênicas induzidas por fatores mineralizantes. Dissertação (Mestre em Ciências) - Instituto de Ciências Biomédicas, Universidade de São Paulo, São Paulo, 2009.

Células precursoras de osteoblastos separadas por digestão enzimática de calvárias de ratos crescem e se diferenciam em osteoblastos maduros, que expressam proteínas ósseas e induzem a formação de nódulos de mineral na matriz extracellular (MEC), quando o meio é suplementado com fatores mineralizantes, como o ácido ascórbico (AA) e $\beta$-glicerofosfato ( $\beta G P$ ). Além disso, a adição de glicocorticóides, como a dexametasona (Dex), no meio de cultura, pode aumentar o número de nódulos de mineral e elevar os níveis de osteocalcina em células derivadas de calvária de rato. O fator de transformação de crescimento beta (TGF $\beta$ ) é um fator de crescimento, que desempenha um papel no metabolismo e na remodelação óssea. O presente estudo investigou a influência do TGF $\beta 1$ sobre células osteogênicas induzidas com fatores mineralizantes, comparando a viabilidade e o crescimento celular, a formação de nódulos de mineral in vitro por vermelho de alizarina e von Kossa, e a expressão de proteínas não-colágenas da matriz: osteopontina (OPN), sialoproteína óssea (BSP) e fibronectina (FN). As principais características ultra-estruturais foram examinadas por microscopia eletrônica de transmissão (MET). Todos os experimentos foram realizados se utilizando um controle negativo (sem suplemento) e um positivo para mineralização $(A A+\beta G P)$. O tratamento com TGF $\beta 1$ diminuiu a viabilidade e a proliferação das células, mesmo quando combinado com Dex. A mineralização da MEC foi vermelho de alizarina e von Kossa positiva apenas no grupo tratado com Dex, semelhante ao do controle positivo. Em contraste, o tratamento com TGF $\beta 1$ e TGF $\beta 1+D e x$ foi negativo em todos os períodos estudados, semelhante ao controle negativo. OPN e BSP não foram imunorreativas apenas no controle negativo. Já a FN foi imunorreativa em todos os grupos. Ultra-estruturalmente, a presença de nódulos de mineral foi confirmada, tanto no controle positivo quanto no grupo tratado com Dex, e alterações morfológicas foram observadas nas células tratadas com TGF $\beta 1$ e TGF $\beta 1+D e x$. Sendo assim, os resultados desse estudo mostraram que TGF $\beta 1$ inibe a mineralização da MEC, mesmo quando elas são tratadas com fatores mineralizantes.

Palavras-chaves: Fator de transformação de crescimento - $\beta 1$. Dexametasona. Células osteoprogenitoras. Mineralização in vitro. 


\begin{abstract}
DONATO, T.A.G. Study of the influence of TGF- $\beta 1$ in osteogenic cell culture induced by mineralizing factors. Master Thesis - Instituto de Ciências Biomédicas, Universidade de São Paulo, São Paulo, 2009.

Osteoblast precursor cells separated by the enzymatic digestion of rat calvaria proliferation and differentiate into mature osteoblasts, which express bone-related proteins and induce mineralization of nodules in extracellular matrix (ECM) when the medium is supplemented with mineralizing factors as ascorbic acid (AA) and $\beta$ glycerophosphate ( $\beta G P)$. Moreover, the addition of glucocorticoids, such as dexamethasone (Dex) to the culture medium can increase the number of mineralization nodules and elicit high levels of osteocalcin in primary rat calvarial cells. Transforming growth factor beta (TGF $\beta$ ) is a growth factor which plays a role in metabolism and bone remodeling. The present study investigated the influence of TGF $\beta 1$ on osteogenic cells induced with mineralizing factors, comparing the viability and cell growth, the formation of mineral nodules in vitro by alizarin red and von Kossa histochemistry, and the expression of the noncollagenous matrix proteins osteopontin (OPN), bone sialoprotein (BSP), and fibronectin (FN). The main ultrastructural features were examined by transmission electron microscopy (TEM). All experiments were performed using a negative (without supplement) and a positive control for mineralization $(A A+\beta G P)$. The treatment with TGF $\beta 1$ decreased the viability and growth of cells, even when combined with Dex. The mineralization of ECM was alizarin red and von Kossa positive only in the group treated with Dex, similar to the positive control. In contrast, the cultures treated with TGF $\beta 1$ and TGF $\beta 1+D e x$ were negative in all periods studied, similar to the negative control. OPN and BSP were not immunoreactive only in the negative control. On the other hand, the FN was immunoreactive in all groups. Ultrastructurally, the formation of mineral nodules in the positive control and Dex groups was confirmed. Some morphological changes were seen in cells treated with TGF $\beta 1$ and TGF $\beta 1+D e x$. The results of this study showed that TGF $\beta 1$ inhibits the mineralization of osteogenic cells, even when treated with mineralizing factors.
\end{abstract}

Key words: Transforming growth factor - $\beta 1$. Dexamethasone. Osteoprogenitor cells. In vitro mineralization. 


\section{LISTA DE ILUSTRAÇÕES}

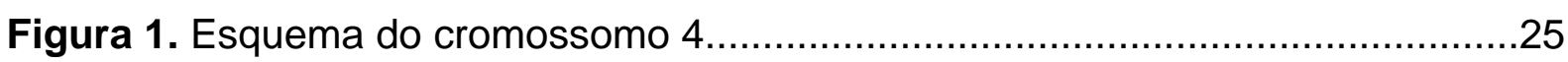

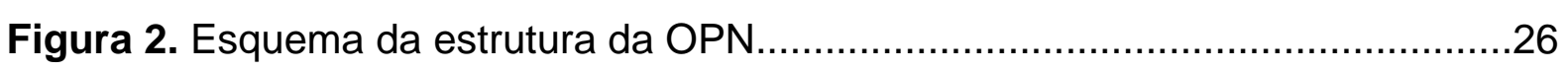

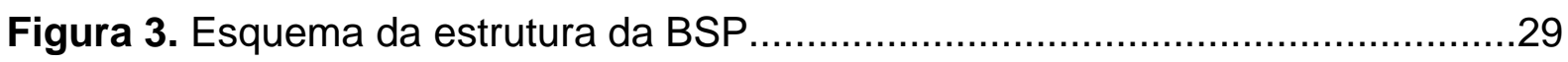

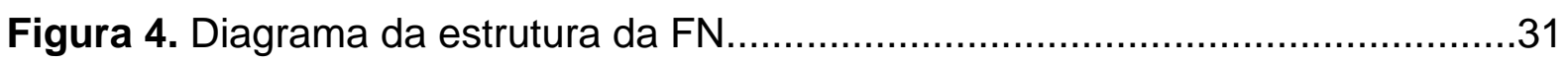

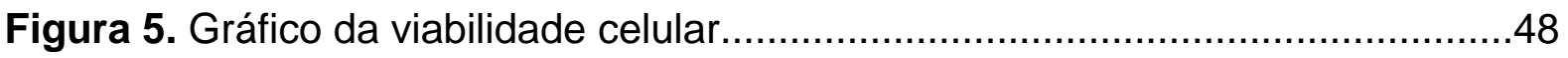

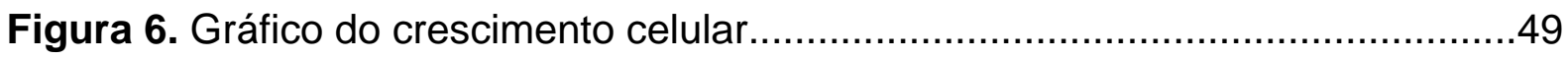

Figura 7. Histoquímica - Vermelho de Alizarina.................................................51

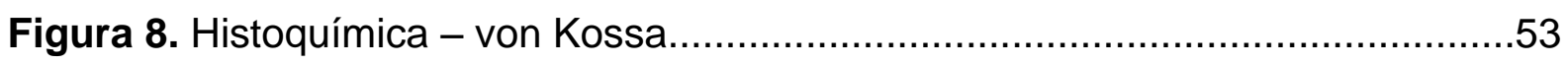

Figura 9. Imunomarcação para OPN em células osteogênicas................................54

Figura 10. Imunomarcação para BSP em células osteogênicas..............................55

Figura 11. Imunomarcaáão par FN em células osteogênicas................................57

Figura 12. Micrografia eletrônica de transmissão de células osteogênicas sem tratamento - controle negativo de mineralização.

Figura 13. Micrografia eletrônica de transmissão de células osteogênicas tratadas com $A A+\beta G P$ - controle positivo de mineralização - matriz.

Figura 14. Micrografia eletrônica de transmissão de células osteogênicas tratadas com $A A+\beta G P$ - controle positivo de mineralização - evolução do processo de mineralização .60

Figura 15. Micrografia eletrônica de transmissão de células osteogênicas tratadas com Dex.

Figura 16. Micrografia eletrônica de transmissão de células osteogênicas tratadas com TGF $\beta 1$. .63

Figura 17. Micrografia eletrônica de transmissão de células osteogênicas tratadas com TGF $\beta 1+D e x$. .64 


\section{LISTA DE ABREVIATURAS E SIGLAS}

$\left(\mathrm{CH}_{3}\right)_{2} \mathrm{SO}$ fórmula química do dimetilsulfóxido

${ }^{\circ} \mathrm{C}$

graus Celsius

AA ácido ascórbico

$\mathrm{AgNO}_{3} \quad$ fórmula química do nitrato de prata

ALP

sigla em inglês para alkaline phosphatase

AR

sigla em inglês para Alizarin red

BGP

sigla em inglês para bone Gla protein

BMP

sigla em inglês para bone morphogenetic protein

BSP

sigla em inglês para bone sialoprotein

$\mathrm{C}_{6} \mathrm{H}_{4}(\mathrm{OH})_{2} \quad$ fórmula química da hidroquinona

$\mathrm{Ca}_{10}\left[\mathrm{PO}_{4}\right]_{6}[\mathrm{OH}]_{2}$ fórmula química da hiodroxiapatita

$\mathrm{CFH} \quad$ sigla em inglês para complement factor $\mathrm{H}$

CFN

sigla em inglês para cellular fibronectin

$\mathrm{CO}_{2}$

fórmula química do dióxido de carbono

Col I colágeno tipo I

DAPI

sigla em inglês para 4,6-diamino-2-phenylindole, dihydrocloride

Dex dexametasona

DMP-1

sigla em inglês para dentin matrix protein 1

DMSO

dimetilsulfóxido

DSPP

sigla em inglês para dentin sialophosphoprotein

FGF sigla em inglês para Fibroblast Growth Factor

$\mathrm{FN}$

fibronectina

$\mathrm{OC}$

osteocalcina

$\mathrm{GC}$

glicocorticóides

Gli

glicina

Glu

ácido glutâmico

GP

sigla em inglês para glicophostate

HA hidroxiapatita

MEC

matriz extracelular 
MEM

MEPE

MET

MMP

MTT

ON

OPN

$\mathrm{OsO}_{4}$

PBS

pFN

$\mathrm{pH}$

RGD

$\mathrm{S}_{2} \mathrm{O}_{3}{ }^{2-}$

SFB

SIBLING

SPARC

TA

TGF

THBS1

TN

vK

sigla em inglês para Minimum Essential Medium

sigla em inglês para matrix extracellular phosphoglycoprotein

microscopia eletrônica de transmissão

sigla em inglês para matrix metalloproteinases

brometo 3-(4,5-dimetilthiazol-2-il)-2,5-difeniltetrazólio]

osteonectina

osteopontina

fórmula química do tetroxido de ósmio

sigla em inglês para phosphate buffer solution

sigla em inglês para plasmatic fibronectin

potencial hidrogeniônico

sequência arginina-glicina-aspartato

fórmula química do tiossulfato

soro fetal bovino

sigla em inglês para Small Integrin-Binding Ligand, N-linked Glycoprotein sigla em inglês para Secreted Protein, Acidic, Rich in Cysteine temperatura ambiente

sigla em inglês para transforming growth factor

sigla em ingles para thrombospondin 1

tenascina

von Kossa 


\section{LISTA DE SÍMBOLOS}

$\begin{array}{ll}\% & \text { sinal matemático indicativo de porcentagem } \\ \alpha & \text { alfa } \\ : & \text { sinal matemático indicativo de proporção } \\ \sim & \text { sinal matemático indicativo de valor aproximado } \\ \mu \mathrm{g} & \text { microgramas } \\ \mu \mathrm{L} & \text { microlitros } \\ \mu \mathrm{m} & \text { micrômetros } \\ \mathrm{kDa} & \text { kiloDalton } \\ \mathrm{kV} & \text { kiloVolt } \\ \mathrm{M} & \text { molar } \\ \mathrm{mg} & \text { miligrama } \\ \mathrm{mL} & \text { mililitro } \\ \mathrm{mm} & \text { milímetros } \\ \mathrm{mM} & \text { miliMolar } \\ \mathrm{mm} & \text { milímetros quadrados } \\ \mathrm{ng} & \text { nanograma } \\ \mathrm{nm} & \text { nanômetro } \\ \beta & \text { beta }\end{array}$




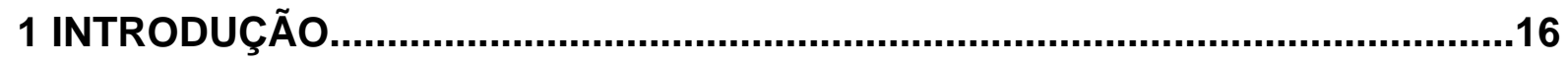

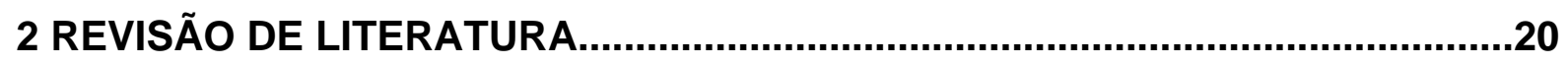

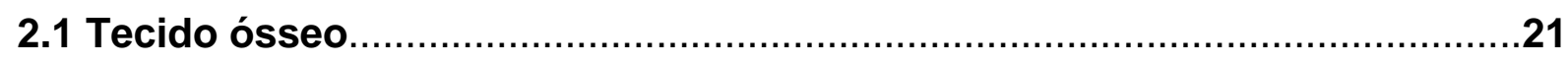

2.2 Fibronectina

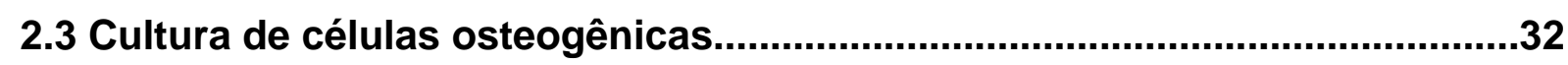

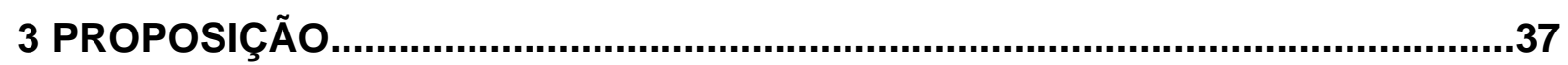

4 MATERIAIS E MÉTODOS...........................................................................39

4.1 Isolamento de células e cultura primária de células osteogênicas...............40

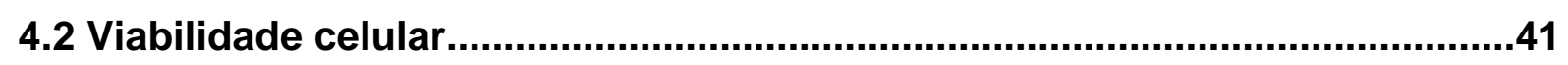

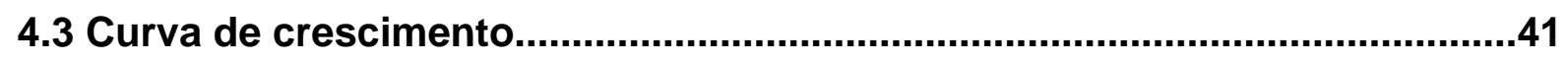

4.4 Caracterização do fenótipo osteogênico........................................................

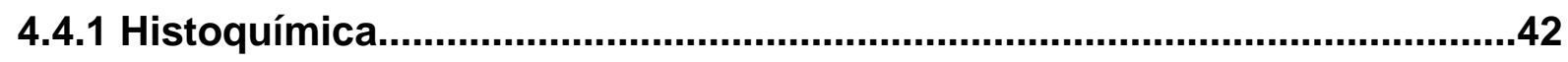

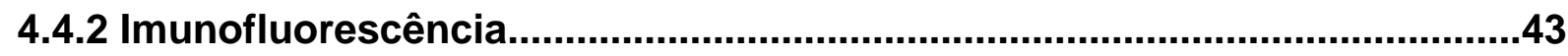

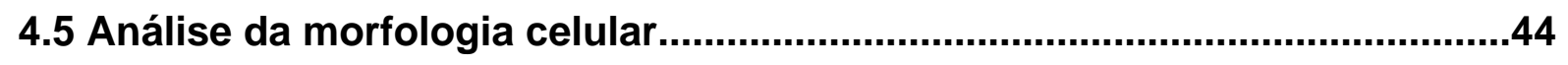

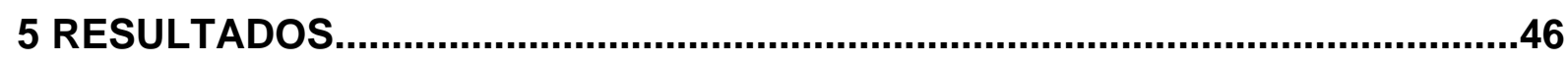

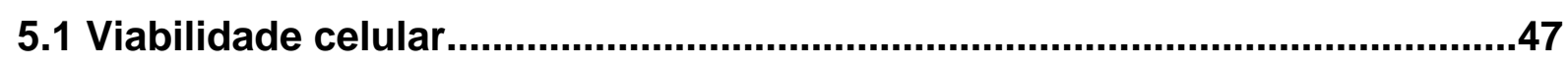

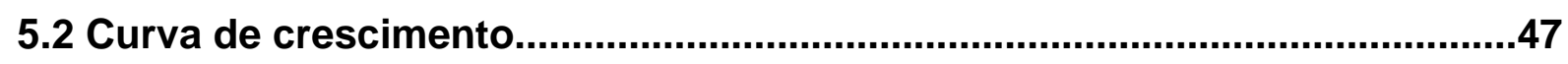

5.3 Caracterização do fenótipo osteogênico.................................................50

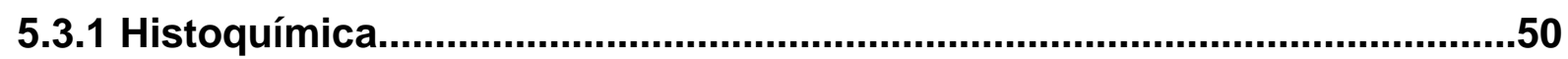

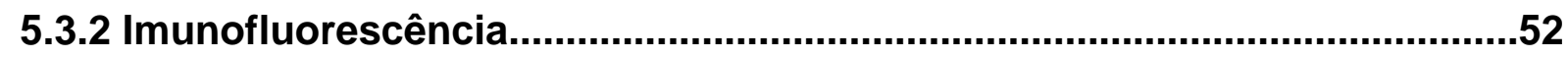

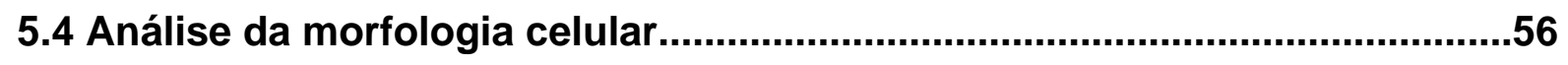

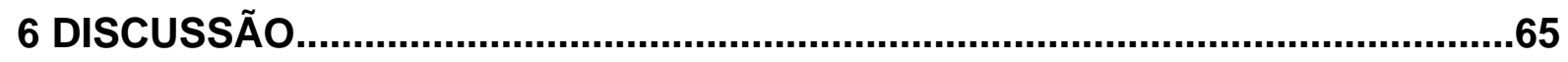

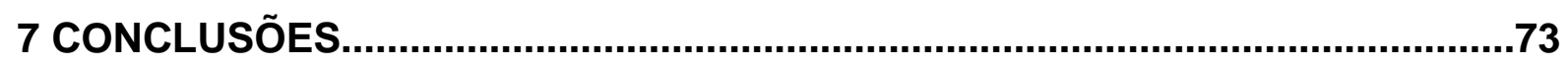

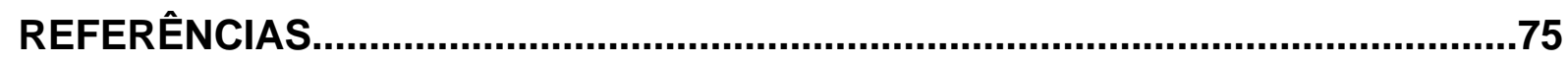


1 INTRODUÇÃO 
O osso é constituído por vários tipos de células e uma abundante matriz mineralizada. A formação óssea, assim como sua reabsorção, é um processo essencial para que se possa manter a estrutura normal do osso, que resultaria na constituição de células: osteoblastos, osteócitos e osteoclastos e matriz, que é caracterizada por uma fase inorgânica - mineral, constituída de fosfato de cálcio, sob a forma de cristais de hidroxiapatita, associada à fase orgânica previamente formada pelos osteoblastos. Essa matriz desempenha um papel molecular e estrutural importante, como armação ou molde do tecido ósseo (KATCHBURIAN e ARANA-CHAVEZ, 2004).

As principais macromoléculas que compõem a matriz orgânica do tecido ósseo são secretadas pelos osteoblastos e são representadas por colágeno, que é uma proteína de fundamental importância na matriz extracelular do tecido conjuntivo. O colágeno é o principal responsável pelas propriedades físicas do tecido, sendo o tipo I (Col I) o mais comum, e as proteínas não colágenas, tais como a osteopontina (OPN), sialoproteína óssea (BSP), osteonectina (ON), osteocalcina (OC), proteínas morfogenéticas ósseas (BMPs) e algumas glicoproteínas, como a tenascina (TN), entre outras, compõem a fase orgânica da matriz. (KATCHBURIAN e ARANA-CHAVEZ, 2004).

Um sistema comumente usado para se estudar a formação óssea in vitro é a cultura primária de células osteogênicas derivadas da calvária de ratos recémnascidos. Esses estudos in vitro mostram que a suplementação do meio de cultura com ácido ascórbico (AA), ßglicerofosfato (BGP) (KASUGAl et al., 1988; NAKASHIMA, 1991; KUO et al., 1992; COUBLE et al., 2000) e dexametasona (Dex) (KASUGAl et al., 1993) induzem células osteogênicas a se diferenciar, ocorrendo, portanto, a formação de uma matriz extracelular mineralizada (KASUGAl et al., 1988; NAKASHIMA, 1991; COUBLE et al., 2000).

Além dos fatores mencionados, quando as células derivadas da calvária de ratos são estimuladas com a adição de dexametasona (Dex), ocorre aumento na atividade de fosfatase alcalina (ALP), na produção de Col I, ON, OC e de outras proteínas não colágenas encontradas no osso (WADA et al.,1998). A expressão de proteínas ósseas está relacionada com a maturação e à aquisição do fenótipo 
osteoblástico. Assim, a Dex, juntamente com AA e $\beta$ GP, tem sido usada na indução de células mesenquimais do estroma, diferenciando essas células em osteoblastos e exibindo mineralização in vitro (MAEGAWA et al., 2007). Boden et al. (1997) mostrou que a diferenciação dessas células induzidas por Dex era verificada pela proteína morfogenética óssea-6 (BMP-6), e não pelo fator de transformação de crescimento-beta 1 (TGF $\beta 1$ ).

A BMP-6 e os TGF $\beta$ fazem parte da superfamília dos fatores de transformação de crescimento (TGF) e incluem TGF $\beta$, activinas e BMPs. Todos esses têm papel regulatório em muitos aspectos da função celular $e$, conseqüentemente, apresentam diversos efeitos em uma variedade de células e tecidos (KINGSLEY, 1994; REDDI, 1980; TOYONO et al., 1997).

O TGF $\beta$ é um dos fatores de crescimento mais abundantes secretados pelas células ósseas, e ele é responsável pelo crescimento e desenvolvimento, proliferação e diferenciação das células do osso. Três isoformas de TGF $\beta$ (TGF $\beta 1$, $\beta 2$ e $\beta 3$ ) têm sido encontradas em humanos e animais, o que tem mostrado que elas agem como um fator anabolizante, melhorando a formação óssea e promovendo a proliferação de osteoblastos, assim como a produção de matriz extracelular, incluindo colágeno, osteonectina, osteopontina e fibronectina (CENTRELLA et al., 1994). Esses eventos também têm sido encontrados em culturas de osteoblastos, e duas das maiores funções do TGF $\beta$ in vitro são a proliferação celular e a formação de matriz extracelular (LUO et al., 2002 ).

O TGF $\beta 1$ é um regulador multifuncional do crescimento e diferenciação celular durante o desenvolvimento e a reparação, influenciando a produção da matriz extracelular (ROBERTS et al., 1987). Além disso, modula também a síntese de receptores de membrana (integrinas), que constituem a principal família de moléculas que intermedeiam interações entre as células e a matriz extracelular, influenciando, direta ou indiretamente, numerosos aspectos do comportamento celular - adesão e migração, proliferação e também diferenciação (DE ARCANGELIS E GEORGES-LABOUESSE, 2000).

No presente estudo, investigar-se-á a expressão de alguns componentes da matriz extracelular em cultura primária de células osteoblásticas de ratos recém- 
nascidos, induzidas in vitro, para a formação de matriz mineralizada, se comparando com outros meios de cultura acrescidos com TGF $\beta 1$ e/ou Dex, através de métodos histoquímicos (vermelho de alizarina e von Kossa) e imunofluorescência para verificação de proteínas não colágenas, em diferentes estágios de mineralização, se avaliando, também, as principais características ultraestruturais das células estudadas e da matriz mineralizada. 
2 REVISÃO DE LITERATURA 


\subsection{Tecido ósseo}

O tecido ósseo é um tecido mineralizado de natureza conjuntiva que se dispõe formando os ossos, estruturas rígidas e resistentes que formam o esqueleto. Suas funções incluem a manutenção dos níveis de cálcio no sangue, fornecer apoio mecânico aos tecidos moles e servir de alavanca para a ação muscular; participa da hematopoiese e protege o cérebro e a medula espinhal (HARADA e RODAN, 2003).

A formação óssea, assim como sua reabsorção, é um processo essencial para que se possa manter a estrutura normal do osso. O osso é constituído por células e uma abundante matriz mineralizada.

As células são representadas pelos osteoblastos, responsáveis pela síntese e mineralização da matriz extracelular (MEC); pelos osteoclastos, que participam da remodelação óssea e da homeostase do cálcio no corpo; e pelos osteócitos, que situam-se dentro da matriz óssea mineralizada (YAMAMOTO et al., 2002).

Os osteoblastos são células de origem mesenquimal, envolvidos na síntese e mineralização da matriz óssea. Devido a isso, suas características morfológicas são de células em alta atividade de síntese e secreção, ou seja, o citoplasma é repleto de retículo endoplasmático rugoso (RER), complexo de Golgi (CG) bem desenvolvido e grande quantidade de vesículas de secreção (KATCHBURIAN e ARANA-CHAVEZ, 2004).

Os osteoblastos podem: ficar aprisionados na matriz mineralizada como osteócitos; transformar-se em osteoblastos inativos - denominados como células de revestimento ósseo ou bone lining cells (HIRASHITA, 1976); ou ainda, sofrerem morte programada (apoptose) (NOBLE et al., 1997; JIKA et al., 1998; Manolagas, 2000; Li et al., 2004; FRANZ-ODENADAAL et al., 2006).

Os osteócitos são células achatadas; o RER e CG são diminuídos, ou seja, sua atividade metabólica é escassa. Entretanto, são indispensáveis na manutenção da homeostase óssea (KATCHBURIAN e ARANA-CHAVEZ, 2004). Eles são as células mais abundantes do tecido ósseo (FRANZ-ODENDAAL et al., 2006), e apesar de estarem presos em lacunas na matriz mineralizada, os osteócitos, através de uma rede de canalículos, interconectam seus prolongamentos, permitindo a difusão de 
nutrientes e pequenas moléculas, além de fazerem contato com outros osteócitos, células de revestimento ósseo e osteoblastos, através de junções comunicantes (gap juctions) (KATCHBURIAN e ARANA-CHAVEZ, 2004).

Diferente dos osteoblastos e dos osteócitos, os osteoclastos são células móveis, multinucleadas, formadas a partir de células mononucleares derivadas do tecido hematopoiético que, sob estímulos específicos se fusionam e aderem ao tecido ósseo (LENER, 2001), sendo responsáveis pela reabsorção do mesmo. Eles não apenas se unem à superfície mineralizada, mas também isolam o microambiente entre eles e a superfície do osso, tornando-o assim favorável à reabsorção óssea. Quando estão ativos apresentam uma borda em escova, região mais ativa, podendo apresentar várias regiões correspondentes, caso estejam apostos ao osso em mais de um ponto (DELAISSE et al., 2003; ARANA-CHAVEZ e BRADASCHIA-CORREA, 2009).

Produzida pelos osteoblastos, a MEC tem papel molecular e estrutural importante na armação ou molde do tecido ósseo, e consiste em várias classes diferentes de moléculas que podem regular a modelação e a remodelação do mesmo. A MEC contém componentes estruturais como a fibronectina (FN) e o Col I, assim como proteases que degradam a matriz (NORDAHL et al.,1995; GLOBUS et al., 1998). Ela também serve como reservatório de fatores de crescimento das superfamílias do TGF $\beta$ e fator de crescimento fibroblástico (FGF) (CANALIS et al., 1993). Esses componentes, juntos ou sozinhos, são produzidos pelos osteoblastos, podendo subseqüentemente afetar a diferenciação ou a sobrevivência, agindo como uma feedback para regular a formação óssea.

A MEC é caracterizada por uma fase mineral (representada por $65 \%$ do peso do osso), constituída por fosfato de cálcio, sob forma de cristais de hidroxiapatita $\left(\mathrm{HA}-\mathrm{Ca}_{10}\left[\mathrm{PO}_{4}\right]_{6}[\mathrm{OH}]_{2}\right)$ associada a uma fase orgânica $(35 \%)$, rica em Col I, chamada de osteóide (KATCHBURIAN e ARANA-CHAVEZ, 2004). Além do Col I, ela contém várias proteínas não colágenas, que compreendem aproximadamente $10 \%$ da matriz orgânica no osso maduro. Acredita-se que essas proteínas promovam e controlem a mineralização das fibras de colágeno e o crescimento dos 
cristais de HA dentro do osteóide (KATCHBURIAN e ARANA-CHAVEZ, 2004; QIN et al., 2004; OGATA, 2008).

Entre as proteínas não colágenas sintetizadas pelas células ósseas estão: a ON, também conhecida como SPARC (secreted protein, acidic, rich in cysteine), que é uma glicoproteína e está presente em grandes concentrações no osso; SIBLING

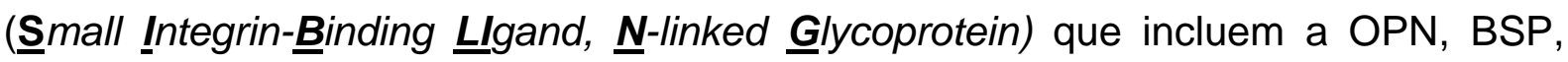
proteína de matriz dentinária 1 (DMP-1), e fosfoglicoproteína de matriz extracelular (MEPE) (FISHER et al., 2001; QIN et al., 2004); a OC ou proteína Gla óssea (BGP); entre outras, incluindo FN (BELLOWS et al., 1991; RODAN e NODA, 1991; MOURSI et al., 1997; WADA et al., 1998; PÚRPURA et al., 2004, OGATA, 2008). Dessas proteínas, apenas a OC e BSP são específicas dos tecidos mineralizados (BIANCO et al., 1991; MASSA et al., 2005), enquanto outras, como a Onec e OPN, têm uma distribuição mais abrangente (NODA, 1993; SODEK e McKEE, 2000; FISHER e

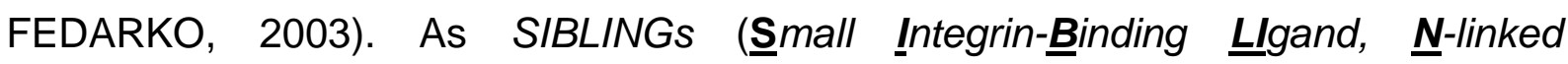
Glycoprotein), uma família de cinco glicofosfoproteínas que compreendem a BSP, OPN, DMP1, DSPP e MEPE (FISHER et al., 2001; QUIN et al., 2004; OGATA, 2008), foram assim denominadas baseando-se não em teorias atuais de suas funções (o que é pouco sabido), mas na bioquímica e nas características genéticas que são compartilhadas pelos membros dessa família.

Elas são encontradas principalmente nos tecidos mineralizados de natureza conjuntiva, os quais têm a HA como seu componente mineral. As proteínas dessa família são secretadas na MEC durante a formação e mineralização desses tecidos, exercendo papel direto na nucleação ou na inibição dos cristais de HA (HUNTER et al., 1996).

As SIBLINGs foram definidas estruturalmente por apresentarem sequências conservadas nos seus exons, incluindo a abundância de aminoácidos ácidos, a sequência arginina-glicina-aspartato (RGD) e por suas modificações póstraducionais (casina quinase, fosforilação e vários eventos de glicosilação). Elas são definidas como pequenas, solúveis, e que se ligam a diferentes famílias de proteínas, incluindo as integrinas - através da sequência RGD ou não RGD - e a outras proteínas de superfície celular, tais como: membros da família matriz metaloproteinase (MMP) e complemento fator $\mathrm{H}(\mathrm{CFH})$, o que as distinguem de 
proteínas de matriz maiores, como a FN, colágeno e trombospondina (THBS1) (BELLAHCÈNE et al., 2008).

Além disso, a organização dos seus genes é semelhante, apresentando um ou dois exons finais maiores contendo o tripeptídeo RGD. Essas partes comuns se localizam no cromossomo 4q21-23 (Fig. 1) (MACDOUGALL et al., 1997; GANSS et al.; 1999; QUIN et al., 2004). Os genes, ainda, compartilham semelhanças nas modificações pós-traducionais, sendo que algumas das suas funções biológicas são dependentes dessas, tais como a fosforilação e a glicosilação.

A OPN e BSP são ambas sialoproteínas fosforiladas, ricas em aminoácidos ácidos, contendo uma sequência RGD responsável pela ligação entre célula/matriz. Elas serão abordadas com maior detalhe a seguir.

\section{a) Osteopontina (OPN)}

A OPN foi identificada pela primeira vez por Fanzen and Heinegard em 1985 (HAYLOCK e NILSSON, 2006), tratando-se de uma glicoproteína fosforilada, de 34 kDa, que contém $5 \%$ de ácido siálico e uma extensão de nove resíduos consecutivos de ácido aspártico, sendo rica em grupo fosfato (Fig. 2). O nome osteopontina foi introduzido a essa proteína para refletir o alto potencial dessa proteína nos tecidos mineralizados de servir como "ponte" entre as células e a HA (SODEK et al., 2000, QUIN et al., 2004, STANDAL et al., 2004a, NANCI et al., 2004).

A OPN compreende, aproximadamente, $2 \%$ das proteínas não colágenas no osso (McKEE e NANCI, 1996; DENHARDT et al., 2001a), e embora ela seja sintetizada em grandes quantidades, também está presente em outros tecidos, células e fluídos corporais (SODEK e McKEE, 2000; QUIN et al., 2004; STANDAL et al., 2004b). Sua ampla expressão indica uma diversidade de funções em diversos eventos biológicos, tais como: processos fisiológicos e patológicos, incluindo a adesão celular (REINHOLT et al., 1990); angiogênese (ASOU et al., 2001); apoptose; respostas inflamatórias e metástases (DENHARDT et al., 2001b). Isso acontece porque a molécula de OPN apresenta várias formas, muitos receptores e sítios de ligação (DENAHARDT e GUO, 1993). 


\section{CROMOSSOMO 4}

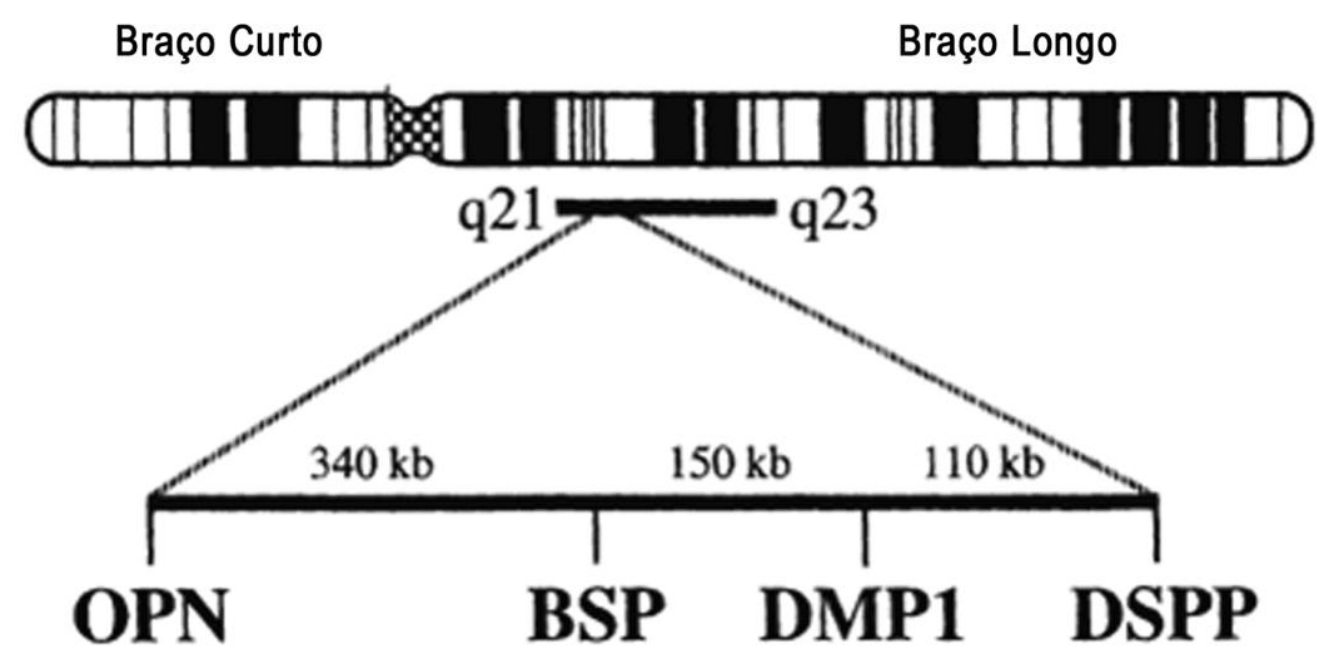

Figura 1: Cromossomo 4. As proteínas da família SIBLING: OPN, BSP, DMP1 e DSPP, estão localizadas em q21-q23 do braço longo do cromossomo 4.

Fonte: GANSS et al., 1999. 


\section{ESTRUTURA DA OSTEOPONTINA}

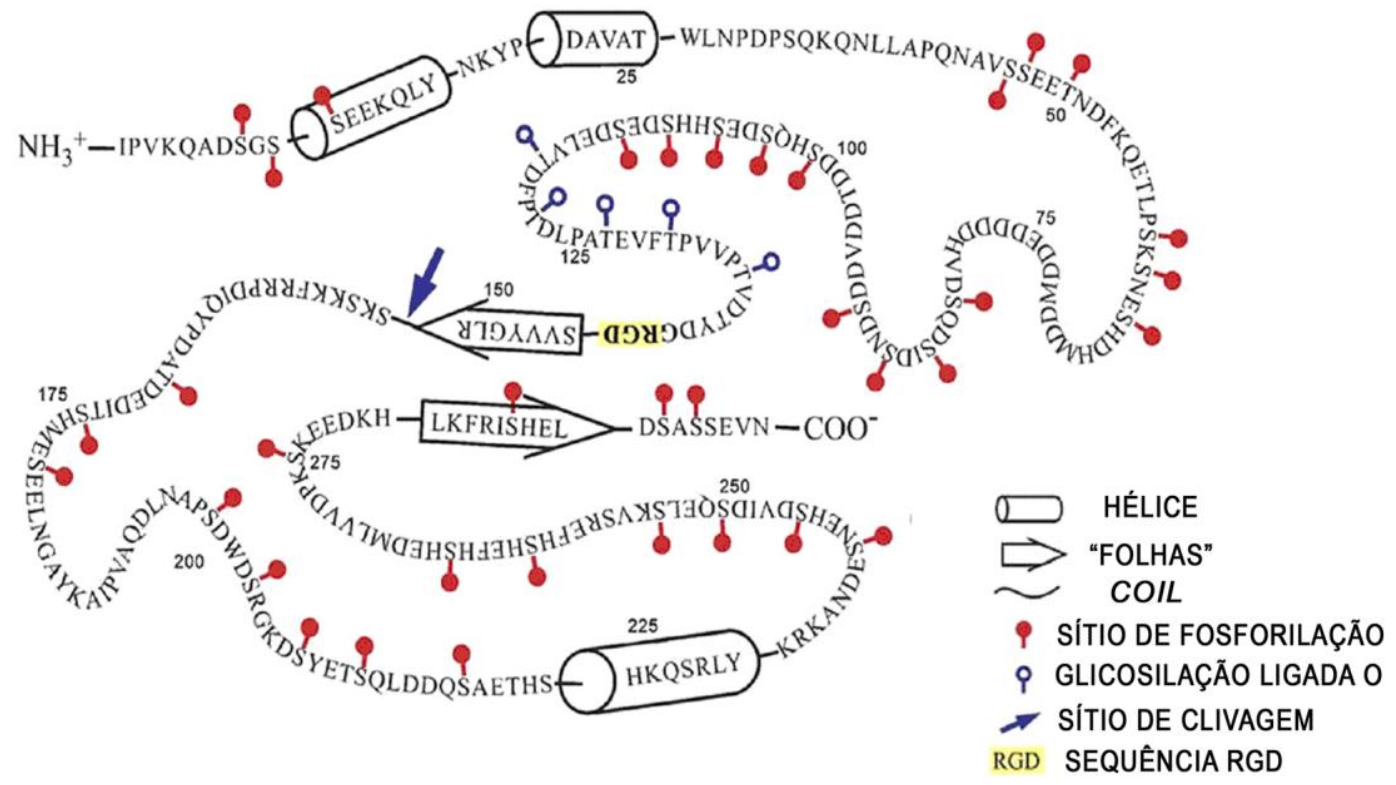

Figura 2: Esquema da estrutura da osteopontina. Ela é uma proteína glicosilada fosforilada, portanto apresenta vários sítios de glicosilação (vermelho) e fosforilação (azul), é rica em ácido poliaspártico e tem afinidade por vários receptores celulares que são reconhecidos pela sequência RGD que está localizada na porção central (grifado em amarelo).

Fonte: KAZANECKI et al., 2007. 
A OPN tem afinidade por vários receptores celulares, incluindo $\alpha_{\mathrm{v}} \beta_{3}$ (LIAW et al., 1995), $\alpha_{v} \beta_{5}$ e $\alpha_{v} \beta_{1}$ (HU et al., 1995). Muitos desses sítios de ligação de integrinas reconhecem a sequência $R G D$. Esses receptores mediam à adesão de uma variedade de células para a OPN, o que resulta em diferentes funções celulares, tais como a motilidade celular. Além dos receptores da superfície celular, a OPN pode se ligar a proteínas da MEC, tais como: FN e Col (ALFORD e HANKENSON, 2006). Ela também pode ligar-se ao cálcio - através do seu domínio poliaspártico, e tem sido descrita tanto na mineralização como na reabsorção óssea.

A OPN é a primeira a ser expressa durante o período de proliferação, após o que apresenta uma diminuição, e volta aumentar no início da mineralização, atingindo níveis máximos durante a mesma (ZOHAR et al., 1998). Ela é secretada por diferentes células ósseas, e o aumento da sua expressão está associada à remodelação óssea (McKEE e NANCI, 1995; SODEK et al., 1995), e acúmulos de focos minerais entre as fibras de colágeno e nas linhas cimentantes (NANCI, 1999). Isto acontece porque a OPN tem uma alta afinidade pelos cristais de HA, fazendo com que essa proteína esteja presente em matrizes calcificadas, locais de modulação, de formação e no crescimento de cristais de mineral (HUNTER et al., 1994). Entretanto, em estágios de diferenciação das células osteogênicas essa afinidade pode ser menor, e a proteína secretada menos fosforilada (SODEK e McKEE, 2000).

A expressão da OPN é afetada por um grande número de hormônios, citocinas e fatores de crescimento. Ela é aumentada quando existe algum tipo de lesão ou doença, e está estritamente associada com depósitos ectópicos calcificados (STEITZ et al., 2002; BELLAHCÈNE et al., 2008; OGATA, 2008). Ela também aparece durante o desenvolvimento de alguns tumores, particularmente aqueles que têm tendência a fazer metástase no osso (FISHER et al., 2001).

\section{b) Sialoproteína Óssea (BSP)}

A BSP foi a primeira proteína não colágena isolada e purificada, a partir do osso cortical bovino, por Herring and Kent (GANSS et al., 1999) e, 
subsequentemente, caracterizada por Fisher (QUIN, 2004) como uma glicoproteína com um alto teor de ácido siálico.

Diferente da OPN, a distribuição da BSP é restrita, sendo encontrada exclusivamente em tecidos mineralizados, como: osso; dentina; cartilagem calcificada, e cemento. No osso e no cemento, ela representa de 8 a $12 \%$ do total das proteínas não colágenas (FISHER et al., 1990), sendo inferior ( 1\%) na dentina (FUJISAWA et al., 1993).

Apesar das funções biológicas da BSP nos tecidos mineralizados serem desconhecidas, acredita-se que ela atue como um nucleador em potencial da HA (HUNTER e GOLDBERG, 1994; GANSS et al. 1999; OGATA, 2008), bem como um marcador da diferenciação osteoblástica e cementoblástica.

Assim como todas as proteínas da família SIBLINGs, a BSP também apresenta uma seqüência RGD, localizada na porção caboxi-terminal ( $\mathrm{COOH}$-teminal), que é capaz de ligar-se a integrinas $\left(\alpha_{v} \beta_{3}\right.$ e $\left.\alpha_{v} \beta_{5}\right)$ das superfícies celulares (Fig. 3) (BELLAHCÈNE et al., 2008). A BSP pode, então, contribuir na ativação dos osteoclastos, participando da remodelação óssea, além de desempenhar vários papéis em patologias (GANSS et al., 1999; RAZZOUK et al., 2002).

Em mamíferos, a BSP é composta por 321 aminoácidos, incluindo uma sequência de 16 aminoácidos sinal. A proteína madura tem peso molecular de 33-34 kDa, e contém predominantemente resíduos de ácido glutâmico (Glu) e glicina (Gli) que constituem $\sim 33 \%$ do total de aminoácidos. A grande quantidade de Glu está em 2 3 trechos de ácido poliglutâmico (poli-Glu), localizado na metade da porção amino-terminal (N-terminal) da molécula de BSP, onde acredita-se ocorram as ligações com a HA (GANSS et al., 1999; OGATA, 2008).

A BSP de ratos contém uma sequência três sítios pontuais de Asn-X-Ser/Thr de glicosilação, que estão localizados na porção N-terminal, próximos ao meio da estrutura da proteína (SHAPIRO et al., 1993), sendo que dois deles são conservados em mamíferos. Embora não se saiba a função exata, a extensa glicosilação da BSP pode afetar a atividade de ligação com as células, mas não a nucleação e a formação da apatita (HUNTER e GOLDBERG, 1994; GOLDBERG et al., 1996). 


\section{ESTRUTURA DA SIALOPROTEÍNA ÓSSEA}

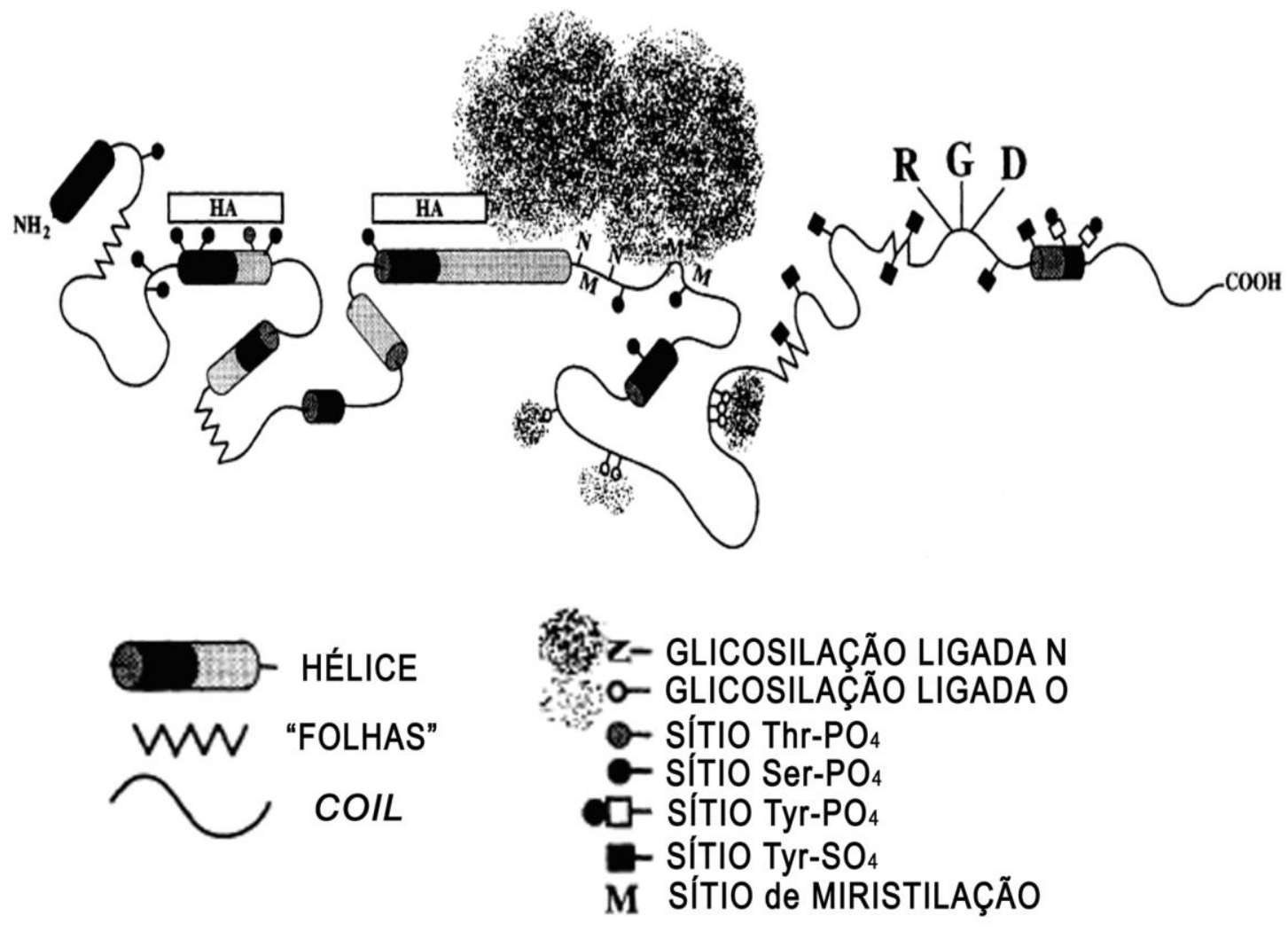

Figura 3: Esquema da estrutura da BSP. A BSP é uma proteína glicosilada rica em ácido siálico e que apresenta trechos de ácido poliglutâmico, que interagem com hidroxiapatita (HA). Ela é rica em sítios de fosforilação (ser/thr), que estão distribuídos ao longo de toda estrutura. A seqüência RGD - apresenta afinidade por vários receptores celulares, e está localizada próximo ao carbono-terminal em uma região coil, cercado por sítios $\mathrm{Tyr}_{-\mathrm{SO}_{4}}$ e separada por sítios de glicosilação $(-\mathrm{O}$ ou $-\mathrm{N})$ da região de afinidade a HA.

Fonte: GANSS et al., 1999. 
Apesar da BSP ser exclusiva de tecidos mineralizados, alguns trabalhos relatam sua expressão em metástases ósseas de tumores: de mama, pulmão, tireóide e próstata, ou quando há algum tipo de lesão ou doença associada a depósitos de cálcio (PÉCHEUR et al., 2002; BELLAHCÈNE et al., 2008; OGATA, 2008).

\subsection{Fibronectina (FN)}

As FNs são glicoproteínas adesivas grandes; são compostas por duas subunidades similares ou idênticas, com peso molecular de $220 \mathrm{KDa}$ cada, ligadas por duas pontes dissufeto. Existem pelo menos vinte cadeias distintas de FN, todas geradas por um único gene. Cada peptídeo consiste em seis domínios altamente flexíveis contendo uma sequência de três aminoácidos diferentes repetidos (domínios I, II e III) (HYNES e YAMADA, 1982; TETI, 1992; GLOBUS et al., 1998; CAMPBELL, 2008; KADLER et al., 2008; LEISS et al., 2008).

Esses domínios mediam a interação com as células e componentes da matriz (incluindo colágeno) e outras moléculas de FNs (KADLER et al., 2008). Além desses domínios, contêm uma sequência RGD na FN III, que está presente na maioria das proteínas adesivas e que reconhece vários membros da família das integrinas, incluindo o receptor específico $\alpha_{5} \beta_{1}$ (TETI, 1992; MOURSI et al., 1996; GLOBUS et al., 1998; CAMPBELL, 2008) (Fig. 4).

Dentre as propriedades dessa molécula estão a adesão celular, a morfologia, a organização do citoesqueleto, a migração, a diferenciação, a transformação oncogênica, a fagocitose e a hemostasia. Ela é capaz de interagir especificamente com uma grande variedade de macromoléculas, e tanto in vivo como in vitro, interage com colágeno, fibrina, heparina e proteoglicanas (HYNES e YAMADA, 1982, YAMADA et al., 1992, MOURSI et al., 1996).

Há duas formas de FNs: a FN celular (CFN), que está presente em células e tecidos onde são sintetizadas e montam uma matriz fibrilar; e a FN plasmática (pFN), que é produzida por hepatócitos e secretada na corrente sanguínea, onde permanece na forma não fibrilar - solúvel (LEISS et al., 2008). In vivo, as FNs são 


\section{ESTRUTURA DA FIBRONECTINA}

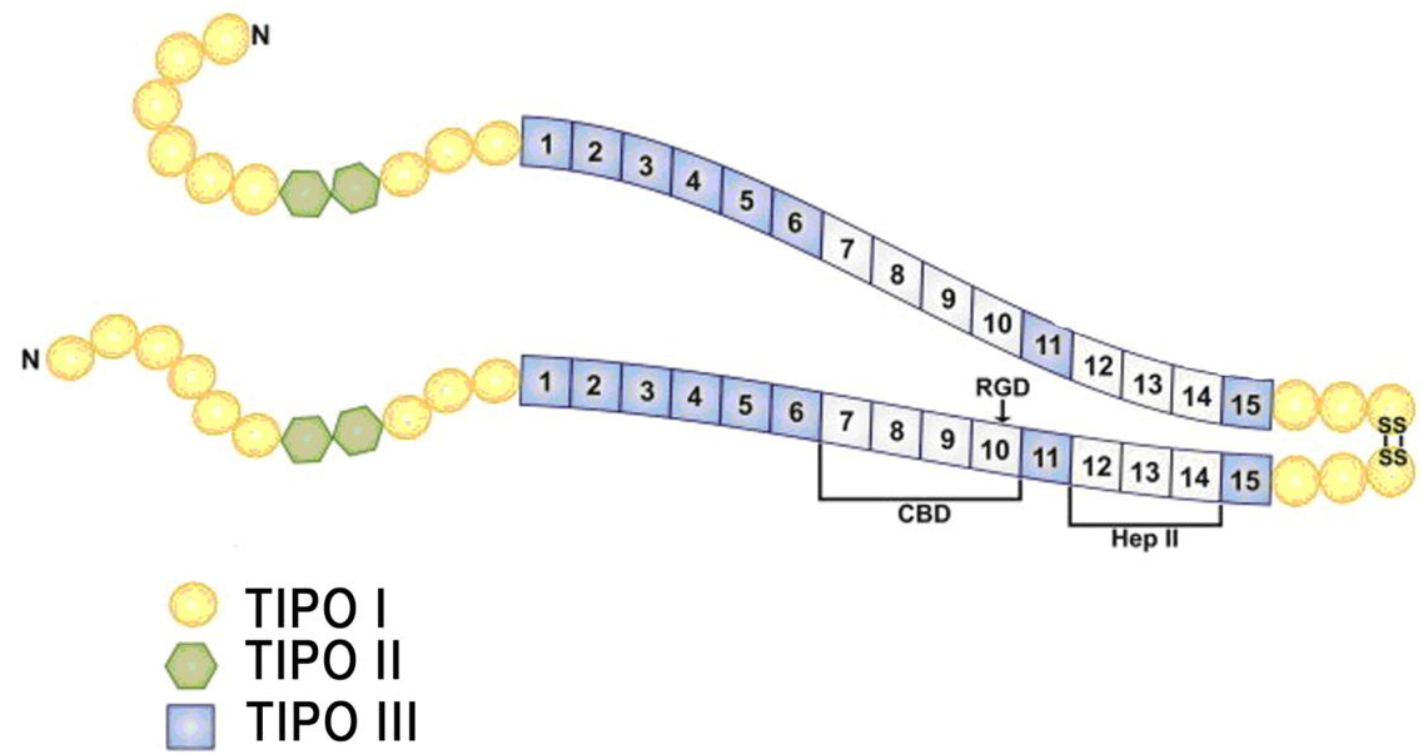

Figura 4: Diagrama da estrutura da fibronectina dimérica. As pontes dissulfetos ligadas a cadeias polipeptídicas idênticas constituem homólogos do tipo I (círculos), II (hexágonos) e III (quadrados). A seqüência RGD contém domínios de ligação celular (CBD) e domínios Hep II que estão indicados por quadrados sombreados.

Fonte: FARALLI et al., 2009. 
encontradas em fluidos corporais, na matriz dos tecidos moles e na maioria das membranas basais; e in vitro são sintetizadas por uma variedade de células, tais como: fibroblastos, osteoblastos, condroblastos, hepatócitos, entre outras (HYNES e YAMADA, 1982; MOURSI et al., 1997).

Existem fortes evidências que sugerem que a FN esteja envolvida nos primeiros estágios da osteogênese; ela é sintetizada e depositada em áreas do tecido ósseo onde ocorre o recrutamento de precursores de células osteoblásticas. A expressão do seu RNAm, seguida da tradução e acúmulo na MEC, é elevada durante o início da fase de diferenciação dos osteoblastos, e esses níveis são diminuídos durante a fase de maturação dessas células (STEIN et al., 1990; MOURSI et al., 1997).

In vitro, a expressão da FN pode ser alterada por alguns fatores conhecidos como reguladores da diferenciação osteoblástica, tais como: hormônio para tireoidiano; estrógenos; glicocorticóides; vitamina D e TGF $\beta$, que podem afetar a adesão dessas células (BREEN et al., 1994; MOURSI et al., 1997).

\subsection{Cultura de células osteogênicas}

O sistema de cultivo celular tem sido usado rotineiramente em estudos detalhados da formação óssea em ambientes controlados, em que é possível analisar minuciosamente eventos celulares e da MEC. Além das linhagens de células osteoblásticas e de osteosarcoma, outro sistema in vitro comumente usado é a cultura de células osteogênicas primárias - derivadas de calvárias de ratos (DE OLIVEIRA et al., 2003).

Os osteoblastos e suas células precursoras, isolados através de digestões enzimáticas de calvárias de ratos - fetos ou recém nascidos - em cultura, desenvolvem-se e diferenciam-se até a forma de osteoblastos maduros, expressando proteínas de matriz e produzindo nódulos de mineral in vitro (NEFUSSI et al., 1985; BELLOWS et al., 1986; BELLOWS e AUBIN, 1989; OWEN et al., 1990; DE OLIVEIRA et al., 2007). Os procedimentos para obtenção de células, assim como as condições de cultura e a seqüência temporal para diferenciação e 
expressão de proteínas ósseas de matriz, estão bem definidos para o sistema de cultivo (STEIN e LIAN, 1993).

O desenvolvimento dos osteoblastos geralmente é subdividido em três estágios: proliferação, maturação da matriz e mineralização (OWEN et al., 1990). A capacidade de células osteogênicas diferenciarem-se está relacionada à expressão de proteínas colágenas e não colágenas na MEC e na formação de nódulos de mineral. Nessa fase, a cultura é constituída por múltiplas camadas de células e uma MEC com presença de nódulos mineralizados (FRANCESCHI e IYER, 1992; COUSSENS et al., 2009).

O fenótipo osteoblástico in vitro depende de muitos fatores, como: de onde as células foram isoladas; o meio utilizado; o tempo de cultura; e presença de complementos para proliferação e diferenciação celular (BELOTI e ROSA, 2005). Para que a diferenciação aconteça, são adicionados ao meio de cultura o ácido ascórbico (AA) - que é um co-fator na síntese de colágeno, e o fosfato orgânico (por exemplo, $\beta$-glicerofosfato - $\beta G P$ ), que promovem a mineralização (NEFUSSI et al., 1985; FRANCESCHI, 1992; COUSSENS et al., 2009). Estudos recentes, como, por exemplo, o de De Oliveira (et al., 2007) têm usado ambientes controlados para analisar a regulação celular e a formação da matriz óssea sobre biomateriais. Esses estudos in vitro mostram que a suplementação do meio de cultura com AA e $\beta G P$ induzem células osteogênicas a se diferenciar, ocorrendo, portanto, a formação de uma MEC mineralizada (KASAGAI et al., 1988; NAKASHIMA, 1991; BELLOWS et al., 1992; KUO et al., 1992; COUBLE et al., 2000).

Além do AA e $\beta G P$, existe o acréscimo de indutores específicos, como os glicocorticóides, por exemplo, a dexametasona (Dex) e outros esteróides como progesterona ou alguns fatores de crescimento, tais como, o fator de transformação do crescimento - beta (TGF- $\beta$ ) e proteínas morfogenéticas ósseas (BMPs) (TURKSEN e AUBIN, 1991; HUGHES et al., 1995; ISHIDA e HEERSCHE,1997; YAMAMOTO et al., 2002). Esses suplementos criam um ambiente artificial, induzindo a diferenciação osteoblástica de populações de células, ou mimetizam a mineralização da matriz como a formação óssea in vivo (COUSSENS et al., 2009). Os glicocorticóides e o TGF- $\beta$ serão discutidos com mais detalhes a seguir. 


\section{a) Glicocorticóides (GCs) - Dexametasona (Dex)}

Os glicocorticóides (GCs) são análogos ao hormônio humano cortisol, e está envolvido na regulação do estresse fisiológico. Eles têm efeitos idênticos aos desse hormônio e fazem parte de um grupo de fármacos utilizado como imunossupressor e antiinflamatório, sendo a Dex membro desse grupo, atuando no controle da velocidade de síntese de proteínas.

Para obterem os efeitos imunossupressores, esses fármacos são administrados em doses muito superiores às fisiológicas $\left(10^{-7}\right.$ e $10^{-8} \mathrm{M}$ ) (CANALIS, 1996; ABU et al., 2000; ESPINA et al., 2008). Essas super doses e/ou a exposição continua aos GCs têm efeitos potentes sobre os ossos - diminuindo drasticamente 0 número de osteoblastos e da formação óssea, explicando assim, em parte, a maior incidência de apoptose dos osteoblastos, podendo levar à osteoporose (WEISNTEIN et al., 1998; ESPINA et al., 2008; YUN et al., 2009). No entanto, o mecanismo de ação dos GCs sobre o osso ainda não é bem compreendido.

In vitro, os GCs diminuem a replicação das células pré osteoblásticas, mas aumentam a sua capacidade de diferenciação (SHALHOUB et al.,1992; ABU et al., 2000), aumentando, assim, a expressão de proteínas ósseas, tais como, a fosfatase alcalina (ALP), a Col I, a ON, a OC e outras proteínas não colágenas encontradas no osso (WADA et al., 1998; YAMAMOTO et al., 2002), cuja a expressão está relacionada com a maturação e aquisição do fenótipo osteoblástico.

A Dex, juntamente com AA e $\beta G P$, tem sido usada na indução de células mesenquimais do estroma, diferenciando essas células em osteoblastos e exibindo mineralização in vitro (MAEGAWA et al., 2007). Apesar de estimular a formação de nódulos de mineral in vitro, a Dex - que está bem estabelecida em diferentes sistemas de cultivo, vai agir dependendo do estágio de diferenciação das células osteogênicas, podendo regular a diferenciação positivamente ou negativamente (PURPURA et al., 2004). 


\section{b) Fator de transformação do crescimento (TGF-beta)}

O TGF $\beta$ é uma proteína homodímera, com $25 \mathrm{kDa}$, que exerce várias funções no crescimento celular (CANALIS et al., 1991; HERPIN et al., 2004); ele pertence à superfamília dos TGF $\beta$ e foi caracterizada em cinco isoformas: $\beta 1 ; \beta 2 ; \beta 3 ; \beta 4$ e $\beta 5$, mas apenas três foram detectadas em humanos e animais, sendo elas TGF $\beta 1, \beta 2 \mathrm{e}$ $\beta 3$ (ROBERTS e SPORN, 1990, SHEN et al., 2001). Ela foi inicialmente isolada de plaquetas e é conhecida por ser sintetizada por vários tecidos, incluindo o osso, que é uma importante fonte de TGFß1 (CANALIS et al.,1991; LUO et al., 2002; KIM et al., 2006).

O TGF $\beta$ tem papel regulatório em muitos aspectos da função celular e, conseqüentemente, apresenta diversos efeitos em uma variedade de células e tecidos. É responsável por diversos processos celulares, incluindo proliferação, apoptose e maturação dos tecidos durante a embriogênese, tanto em condições fisiológicas como patológicas, através de receptores de superfície celular (KINGSLEY, 1994; REDDI, 1994; TOYONO et al., 1997; CENTRELLA et al., 1998; MASSAGUÉ et al., 2000; SHI e MASSAGUÉ, 2003). Esses mediadores regulam as funções ósseas e o fenótipo dos osteoblastos e de outras células do osso. Eles se ligam a receptores da superfície celular, que por sua vez resultam em respostas celulares, tais como proliferação e diferenciação (HARADA e RODAN, 2003).

O aumento da massa óssea está relacionado com o aumento da síntese de matriz. Isso acontece quando há uma grande produção pelas células, bem como o aumento do número ou da manutenção da abundante matriz existente dentro do tecido. Em condições normais, em osteoblastos, o TGF $\beta$ aumenta a replicação celular e a síntese de colágeno, tendo assim a formação da matriz óssea (CENTRELLA et al., 1988; CANALIS et al., 1991; CENTRELLA et al., 1994).

Acredita-se que o papel do TGF $\beta$ no crescimento do osso possa estar relacionado com a sua capacidade de aumentar a atividade dos osteoblastos, sendo responsável, então, pelo crescimento e desenvolvimento, proliferação e diferenciação das células do osso e, conseqüentemente pelo processo de mineralização e da expressão de marcadores osteoblásticos, como a ALP, pro-Col I, 
OPN, ON e OC (BREEN et al., 1994; IBA et al., 1995), podendo estar envolvido também no processo de cicatrização e reparação (CANALIS et al., 1991).

A isoforma $\beta 1$ (TGF $\beta 1$ ) é um regulador multifuncional do crescimento e diferenciação celular durante $o$ desenvolvimento e a reparação, influenciando a produção da matriz extracelular (ROBERTS et al., 1988). Além disso, modula também a síntese de receptores de membrana (integrinas), que constituem a principal família de moléculas que intermediam interações entre as células e a matriz extracelular, influenciando, direta ou indiretamente, numerosos aspectos do comportamento celular - adesão e migração, proliferação e também diferenciação (DE ARCANGELIS e GEORGES-LABOUESSE, 2000).

A produção de TGF $\beta 1$ e TGFß2 varia conforme as linhagens celulares (KLOEN et al., 1994). Outros autores sugerem que o TGF $\beta$ esteja envolvido na proliferação, diferenciação e síntese de MEC, mas que ele pode estar menos envolvido ou realmente inibir fases posteriores da osteogênese, como a mineralização (BONEWALD e DALLAS, 1994; BREEN et al., 1994; IBA et al., 1995). Essa divergência de efeitos do TGF $\beta$ parece ser dependente do tipo de célula usada no estudo, do estágio de maturação quando o TGF $\beta 1$ é acrescido, das doses e das rotinas de dosagens, das condições escolhidas de cultura, e do fato de existir presença ou ausência de outros fatores (IBA et al., 1996; SHEN et al., 2001). 
3 PROPOSIÇÃO 
O presente trabalho teve como objetivo avaliar:

- A influência do TGF $\beta 1$ em cultura de células osteogênicas induzidas com dexametasona;

- As principais características morfológicas, através de microscopia eletrônica de transmissão, das células osteogênicas cultivadas com diferentes tratamentos;

- A formação de nódulos de mineral in vitro, através de métodos histoquímicos: vermelho de alizarina e von Kossa;

- A expressão de três proteínas não colágenas de matriz relacionadas com a mineralização - OPN, BSP e FN, com e sem a estimulação com TGFß1. 
4 MATERIAIS E MÉTODOS 


\subsection{Isolamento de células e cultura primária de células osteogênicas}

O cultivo das células foi realizado no Laboratório Multiusuários de Cultivo Celular do Departamento de Biologia Celular e do Desenvolvimento do Instituto de Ciências Biomédicas da USP (ICB/USP).

A linhagem celular de osteoblastos foi obtida através da remoção cirúrgica de calvárias de ratos Wistar (Rattus novergicus) recém-nascidos, sob cadeia asséptica, e aprovação prévia do Comitê de Ética em Pesquisa para Animais do ICB/USP (registro $n^{\circ}$ 86/2005). Ela foi obtida por meio de digestões enzimáticas (solução de colagenase e tripsina em tampão-salina - PBS), sequenciais, de fragmentos de calvárias de seis a dez ratos Wistar com dois a três dias de vida pós-natal (OLIVEIRA et al., 2007).

As células enzimaticamente isoladas, em suspensão, foram contadas em hemocitômetro e plaqueadas na densidade de 20000 células/poço ( 110 células $/ \mathrm{mm}^{2}$ em placas de cultura de 24 e 96 poços), dependendo da análise.

Nas primeiras 24 horas, as células foram cultivadas com meio essencial mínimo, modificação alfa ( $\alpha$ MEM - Invitrogen, Burlington, ON, Canadá) contendo $10 \%$ de soro fetal bovino (SFB - Cultilab, Campinas, Brasil) e 1\% de gentamicina (Invitrogen). Esse meio de cultura foi usado durante todos os períodos experimentais como controle negativo de mineralização.

Após esse período, as células tiveram o meio de cultura substituído por meios de cultura suplementados com: $10 \mathrm{mM}$ de $\beta \mathrm{GP}$ (Sigma, St. Louis, MO, EUA) e 50 $\mu \mathrm{g} / \mathrm{mL}$ AA (Sigma), que serviu como meio base para os demais e como controle positivo de mineralização. Esse meio foi suplementado com $5 \mathrm{ng} / \mathrm{mL}$ de TGFß1 (PrepoTech EC, London, UK), ou com $10^{-7} \mathrm{M}$ Dex (Sigma) ou com ambos simultaneamente.

As células foram mantidas em estufa a $37^{\circ} \mathrm{C}$ em atmosfera úmida, contendo $5 \%$ de $\mathrm{CO}_{2}$ e $95 \%$ de ar atmosférico, durante os tempos experimentais. Os meios de cultura foram trocados a cada 3 dias e a progressão celular avaliada por microscópio de fase. 


\subsection{Viabilidade cellular}

Foi usado o método de MTT modificado (DONATO et al., 2009). Esse método avalia a capacidade de redução do sal de tetrazólio [brometo 3-(4,5-dimetilthiazol-2il)-2,5-difeniltetrazólio] (MTT, $5 \mathrm{mg} / \mathrm{mL}$ PBS - Sigma) pela enzima succinato desidrogenases mitocondrial a cristais de fromazan ao final da reação. Tais cristais produzem uma reação de cor característica que pode ser quantificada através da leitura em espectrofotômetro.

Para a análise de viabilidade, as células osteogênicas foram cultivadas em placas de 96 poços ( 110 células $\left./ \mathrm{mm}^{2}\right)$ e as análises da viabilidade celular foram feitas aos 3, 7, 10 e 14 dias após os tratamentos com AA+ $\beta G P$, acrescido ou não com TGFß1 e/ou Dex.

O MTT foi adicionado em cada poço e incubado por 3 horas em estufa a $37^{\circ} \mathrm{C}$. Em seguida, essa solução foi substituída por $100 \mu \mathrm{L}$ de $\left(\mathrm{CH}_{3}\right)_{2} \mathrm{SO}$ (DMSO dimetilsulfóxido, LGCbio, Cotia, SP, Brasil) para a redução do MTT, por 15 minutos.

A quantificação da viabilidade foi feita em espectrofotômetro (SpectraMax plus, molecular devices), com o auxílio do programa SoftMax Pro, utilizando comprimento de onda de $570 \mathrm{~nm}$. Todos os grupos tiveram o $\mathrm{n}=5$ e foram feitos em triplicata. A análise estatística entre os grupos foi realizada utilizando Two-way (ANOVA) e o nível de significância foi de $5 \%(p<0.05)$.

\subsection{Curva de crescimento}

Para embasar 0 teste de viabilidade celular, foram realizadas, simultaneamente, contagens de células com o auxílio da citometria de fluxo. Essa metodologia permitiu uma análise rápida, objetiva e quantitativa das células em suspensão.

As células foram cultivadas em placas de 24 poços $\left(\sim 110\right.$ células $\left./ \mathrm{mm}^{2}\right)$, e as contagens ocorreram nos mesmos períodos dos testes de viabilidade celular, descritos anteriormente. 
As suspensões celulares foram obtidas através da tripsinização dos poços com tripsina/EDTA (Nutricell, Campinas, SP, Brasil), que posteriormente foram inativadas com o próprio meio de cultura. As suspensões de cada tratamento passaram no citômetro de fluxo (GUAVA EASYCYTE MINI) - e o número de células $/ \mu \mathrm{L}$ foi dado utilizando-se o programa Guava EasyCyte Mini Expres Pro Software. A partir desses valores, o número de células foi calculado. A análise estatística entre os grupos foi realizada utilizando Two-way (ANOVA) e o nível de significância foi de $5 \%(p<0.05)$.

\subsection{Caracterização do fenótipo osteogênico}

A caracterização do fenótipo osteoblástico foi feita através dos métodos histoquímicos: vermelho de alizarina e von Kossa (Bonewald et al., 2003), os quais possibilitaram a identificação da presença de cálcio e de fosfato, respectivamente, em áreas nodulares de matriz mineralizada, evidenciada, respectivamente, pelas cores vermelha e preta, bem como pela expressão de algumas proteínas ósseas específicas da matriz extracelular, casos da BSP e OPN, como também a FN, através do método de imunofluorescência.

As células foram cultivadas sobre lamínulas de vidro ( $13 \mathrm{~mm}$ de diâmetro) em placas de 24 poços ( 110 células $/ \mathrm{mm}^{2}$ ).

\subsubsection{Histoquímica}

As análises da formação de nódulos mineralizados foram feitas com 7, 10 e 14 dias de cultura após os tratamentos com $A A+\beta G P$, acrescidos ou não com TGF $\beta 1$ e/ou Dex.

\section{a) Vermelho de alizarina}

Os meios de cultura foram retirados e os poços foram lavados com solução de Hanks (Sigma), pH 7,4. As amostras foram fixadas com álcool etílico 70\%, por uma 
hora, a $4{ }^{\circ} \mathrm{C}$. Elas foram lavadas com PBS, seguido por água destilada e coradas com vermelho de alizarina (Sigma), pH 4,3 por 15 minutos em TA, lavadas e preparadas para análise em microscópio óptico.

\section{b) von Kossa}

Foram retirados os meios de cultura e colocados em cada poço $2 \mathrm{~mL}$ se nitrato de prata $\left(\mathrm{AgNO}_{3}\right)$ por 20 minutos em TA. Em seguida, os poços foram lavados com água destilada e foram colocados $2 \mathrm{~mL}$ de hidroquinona $\left(\mathrm{C}_{6} \mathrm{H}_{4}(\mathrm{OH})_{2}\right)$ por 2 minutos

em TA. Sem lavar, foram colocados $2 \mathrm{~mL}$ de tiossulfato $\left(\mathrm{S}_{2} \mathrm{O}_{3}{ }^{2-}\right)$ por 2 minutos em TA. As amostras foram lavadas com água destilada e preparadas para análise em microscópio óptico.

\subsubsection{Imunofluorescência}

As células osteogênicas foram cultivadas sobre lamínulas de vidro ( 13 mm) em placas de 24 poços ( 110 células/poço). A reação de imunofluorescência foi feita após o quarto dia de tratamento.

Os materiais foram fixados em metanol a $-20{ }^{\circ} \mathrm{C}$ por 6 minutos, e lavados em PBS. Para o bloqueio da marcação inespecífica, as células foram incubadas em leite desnatado a 5\% em PBS, por 30 minutos em TA. A incubação dos anticorpos primários está descrita na tabela 1 , em que os anticorpos estão diluídos em concentrações de trabalho, overnight em câmara úmida e a $4{ }^{\circ} \mathrm{C}$. O controle negativo para reação foi incubado com PBS, substituindo o anticorpo primário. Todos os procedimentos descritos foram precedidos de lavagens em PBS.

Os anticorpos secundários utilizados foram anti-camundongo biotinilado (Vector Laboratories Inc, Burlingame, CA, USA) e anti-coelho biotinilado (Vector) em uma concentração de 1:50, por 30 minutos, e incubados com estreptavidina conjugada com fluoresceína em temperatura ambiente por 30 minutos e protegidos da luz. 
As montagens das lamínulas sobre as lâminas de vidro foram realizadas utilizando-se meio de montagem Vectashield (Vector) conjugado ao DAPI (4', 6diamino-2-phenylindole, dihydrocloride) para visualização dos núcleos. As observações e fotomicrografias foram realizadas em microscópio de fluorescência Eclipse E800 (Nikon), com a câmara digital Nikon DXM1200C. As pranchas das imagens digitais foram montadas com o auxílio do programa Adobe Photoshop (Sistemas Adobe, San Jose, CA, EUA).

Tabela 1 - Anticorpos primários utilizados, origem e procedência

\begin{tabular}{cccc}
\hline Anticorpo & Hospediro & Diluição & Procedência \\
\hline Anti-OPN & Camundongo & $1: 50$ & DSHB $^{*}$ \\
Anti-BSP & Camundongo & $1: 50$ & DSHB $^{*}$ \\
Anti-FN & Coelho & $1: 700$ & Dako \\
\hline
\end{tabular}

* Developmental Studies Hybridoma Bank, University of lowa, USA.

\subsection{Análise da morfologia celular}

As análises da morfologia celular foram feitas em microscopia eletrônica de transmissão (MET) com 7, 10 e 14 dias. As células foram cultivadas, conforme os procedimentos de cultivo celular descritos anteriormente, em lamínulas de plástico (Thermanox- Thermo Scientific Nunc).

As células foram fixadas com uma solução de $4 \%$ de formaldeído e $0,1 \%$ de glutaraldeído em tampão cacodilato a $0,1 \mathrm{M}, \mathrm{pH} 7,4$ por 1 hora e 30 mimutos, em TA, lavadas na própria solução tampão e pós fixadas em 1\% tetróxido de ósmio $\left(\mathrm{OsO}_{4}\right)$, por 1 hora. Após o que foram desidratadas em uma série de concentrações crescentes de etanol, infiltradas e incluídas em resina Spurr. Os blocos obtidos foram aparados e cortados em um micrótomo (MICRON), com a utilização de facas de vidro feitas com um "knife maker" LKB 7800-B. Os cortes semifinos $(1 \mu \mathrm{m}$ de espessura), foram montados em lâminas de vidro, corados em solução alcoólica de azul de toluidina a $0,25 \%$ e observados ao microscópio de luz. A área de interesse foi selecionada e os blocos foram novamente aparados para a obtenção de cortes 
ultrafinos (80 $\mathrm{nm}$ de espessura), em ultramicrótomo Leica Ultracut $\mathrm{R}$ (Leica Instruments, Nussloch, Alemanha), utilizando facas de diamante. Os cortes foram coletados em telas de cobre de 200 "meshes", e foram contrastados com acetato de uranila e citrato de chumbo. As telas contendo os cortes ultrafinos foram analisadas e fotografadas em um microscópio eletrônico de transmissão JEOL 1010 (Jeol USA Inc. Peabody, MA, USA) operando a 80 kV (Martinez et al., 2007). 
5 RESULTADOS 


\subsection{Viabilidade celular}

No $3^{\circ}$ dia de tratamento não houve diferença significante entre os grupos estudados $(p>0,05)$. Já no $7^{\circ}$ dia de tratamento, as células do grupo controle positivo $(A A+\beta G P)$ e TGF $\beta 1+$ Dex tiveram a viabilidade aumentada significantemente, quando comparada ao controle negativo de mineralização - sem tratamento $(\mathrm{p}<0.001$ e $\mathrm{p}<0,05$, respectivamente). Entretanto, as células tratadas separadamente com TGF $\beta 1$ ou Dex não apresentaram uma diferença significante. No $10^{\circ}$ dia de tratamento, as células tratadas com TGF $\beta 1$, Dex e TGF $\beta 1+D e x$ tiveram um discreto aumento comparado ao $7^{\circ} \mathrm{dia}$. No entanto, a viabilidade celular desses grupos foi inferior significantemente ao grupo controle negativo $(p<0.001)$. No $14^{\circ}$ dia de tratamento, foi observado o aumento da viabilidade em todos os grupos, mantendo o padrão imposto no $10^{\circ}$ dia de tratamento, significantemente diferente do controle negativo (Fig. 5).

\subsection{Curva de crescimento}

Com 3 dias de tratamento, os grupos não apresentaram diferenças significantes entre eles $(p>0,05)$. No $7^{\circ}$ dia, entretanto, as células do controle positivo $(A A+\beta G P)$ tiveram um aumento significativo $(p<0,01)$, sendo superior ao número de células do controle negativo de mineralização (sem tratamento), enquanto que nos demais grupos a diferença não foi significante. Ao $10^{\circ}$ dia de tratamento, o controle positivo manteve seu número celular acima do controle negativo e, juntamente com as células do grupo Dex, apresentou uma diferença significante de $p<0,01$ e $p<0,001$, respectivamente. Já as células tratadas com TGF $\beta 1$ e TGF $\beta 1+D e x$ tiveram o número celular inferior aos demais grupos e ao controle negativo, apresentando uma diferença significante deste último de $p<0,001$ e $p<0,05$, respectivamente. Com 14 dias de tratamento, o controle negativo teve um acentuado aumento no número celular, chegando próximo ao número de células do grupo controle positivo - não apresentado diferença significante com esse - e do grupo Dex $(p<0,05)$, que tiveram um discreto aumento em relação ao período anterior. Os grupos TGF $\beta 1$ e TGF $\beta 1+D e x$ mantiveram o mesmo padrão de crescimento, mantendo uma diferença significante de $p<0,001$ do grupo controle negativo (Fig. 6). 


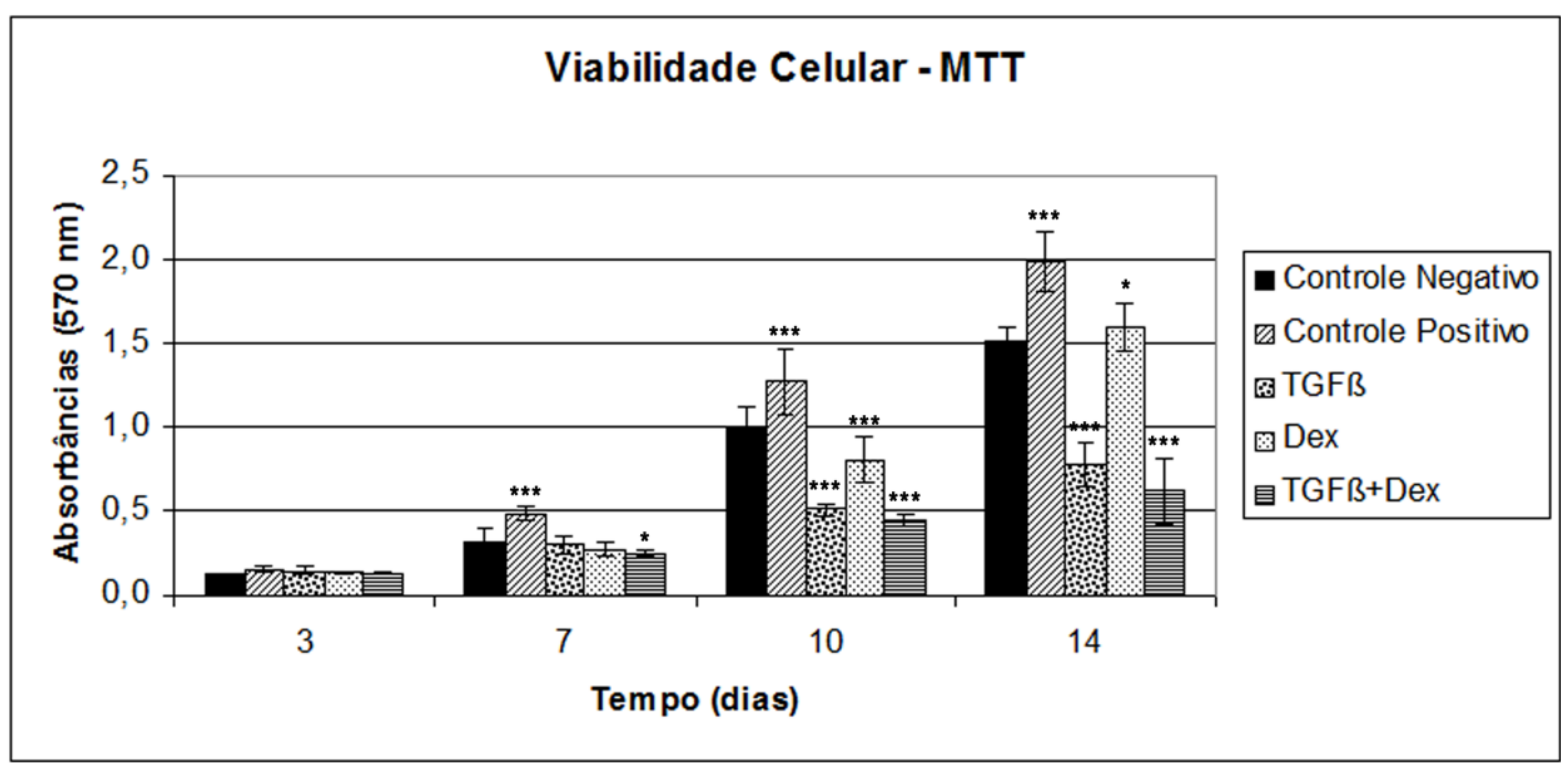

Figura 5: Viabilidade Celular (MTT). Análise da viabilidade celular em cultura de células osteogênicas derivadas de calvárias de ratos com 3, 7, 10 e 14 dias após tratamentos com TGF $\beta 1$ Dex; TGF $\beta 1+D e x$. Controle negativo de mineralização ausência de indutores mineralizantes e Controle positivo de mineralização presença de $A A+\beta G P$. Estatística significante comparada com controle negativo de mineralização, ${ }^{*} p<0,05 ;{ }^{* *} p<0,01 e^{* * *} p<0,001$. 


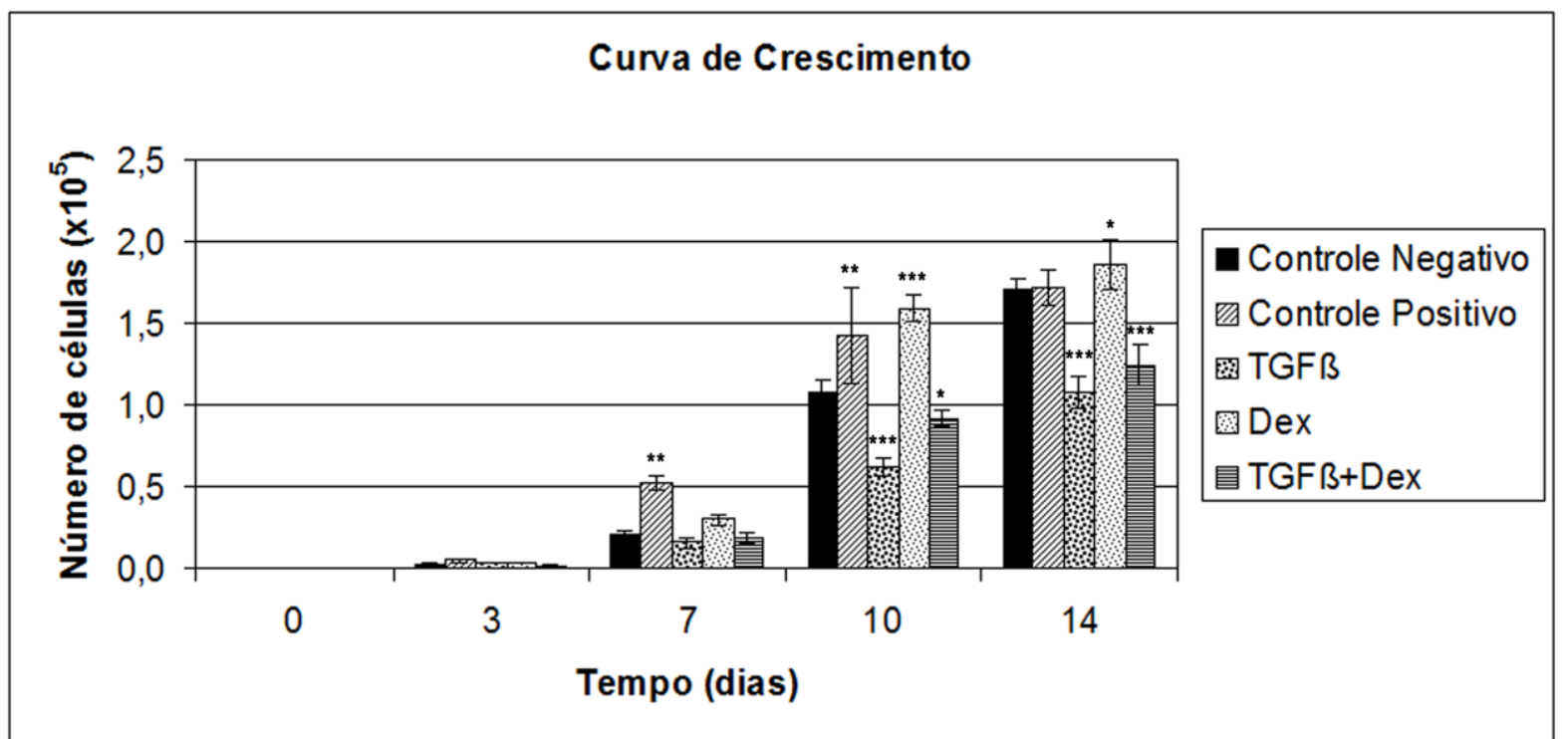

Figura 6: Curva de Crescimento. Contagem celular em cultura de células osteogênicas derivadas de calvárias de ratos com 3, 7, 10 e 14 dias após tratamentos com TGFß1; Dex; TGFß1+Dex, através de citômetro de fluxo (GUAVA EASYCYTE MINI). Controle negativo de mineralização - ausência de indutores mineralizantes e controle positivo de mineralização - presença de $A A+\beta G P$. Estatística significante comparada com controle negativo de mineralização, ${ }^{*} p<0,05 ;{ }^{* *} p<0,01 e^{* * *} p<0,001$. 


\subsection{Caracterização do fenótipo osteogênico}

As células osteogênicas apresentam características particulares, como a formação de nódulos de mineral e expressão de algumas proteínas ósseas in vitro. Tais características podem ser usadas como marcadores do fenótipo osteoblástico, se usadas técnicas específicas.

\subsubsection{Histoquímica}

As análises histoquímicas foram feitas com 7, 10 e 14 dias de cultura após os tratamentos com $A A+\beta G P$ (controle positivo de mineralização), acrescidos ou não com Dex e/ou TGF $\beta 1$. Usamos como controle negativo meio de cultura sem suplementos.

\section{a) Vermelho de alizarina}

Durante os períodos estudados, foi possível observar que as células tratadas com Dex (Fig. 7 G-I) apresentaram o mesmo padrão de mineralização que as células do controle positivo - AA+ $\beta G P$ - (Fig. $7 \mathrm{D}-\mathrm{F})$, isto é, vermelho de alizarina positivo. A positividade para esse corante, destacada em vermelho, indica a presença de cálcio dos nódulos de mineral.

Por outro lado, as tratadas com TGF $\beta 1$, independente da adição ou não de Dex (Fig. 7 J-M e N-P), não reagiram com o corante, não apresentando então, cálcio, o que indica ausência de nódulos de mineral, se assemelhando ao controle negativo (Fig. 7 A-C); porém, a mesma confluência celular não pôde ser observada ao $10^{\circ} \mathrm{e}$ $14^{\circ}$ dia (Fig. 7 C, M e P).

\section{b) von Kossa}

Os resultados do von Kossa reproduziram os que tivemos com vermelho de alizarina. $O$ controle negativo (sem tratamento) não formou nódulos de mineral em nenhum dos períodos estudados, aumentando, com 0 decorrer desses, sua confluência (Fig. 8 A-C). Já o controle positivo $(A A+\beta G P)$ teve as primeiras marcações von Kossa positivo a partir do $10^{\circ}$ dia de tratamento (Fig. 8 D-F) - 


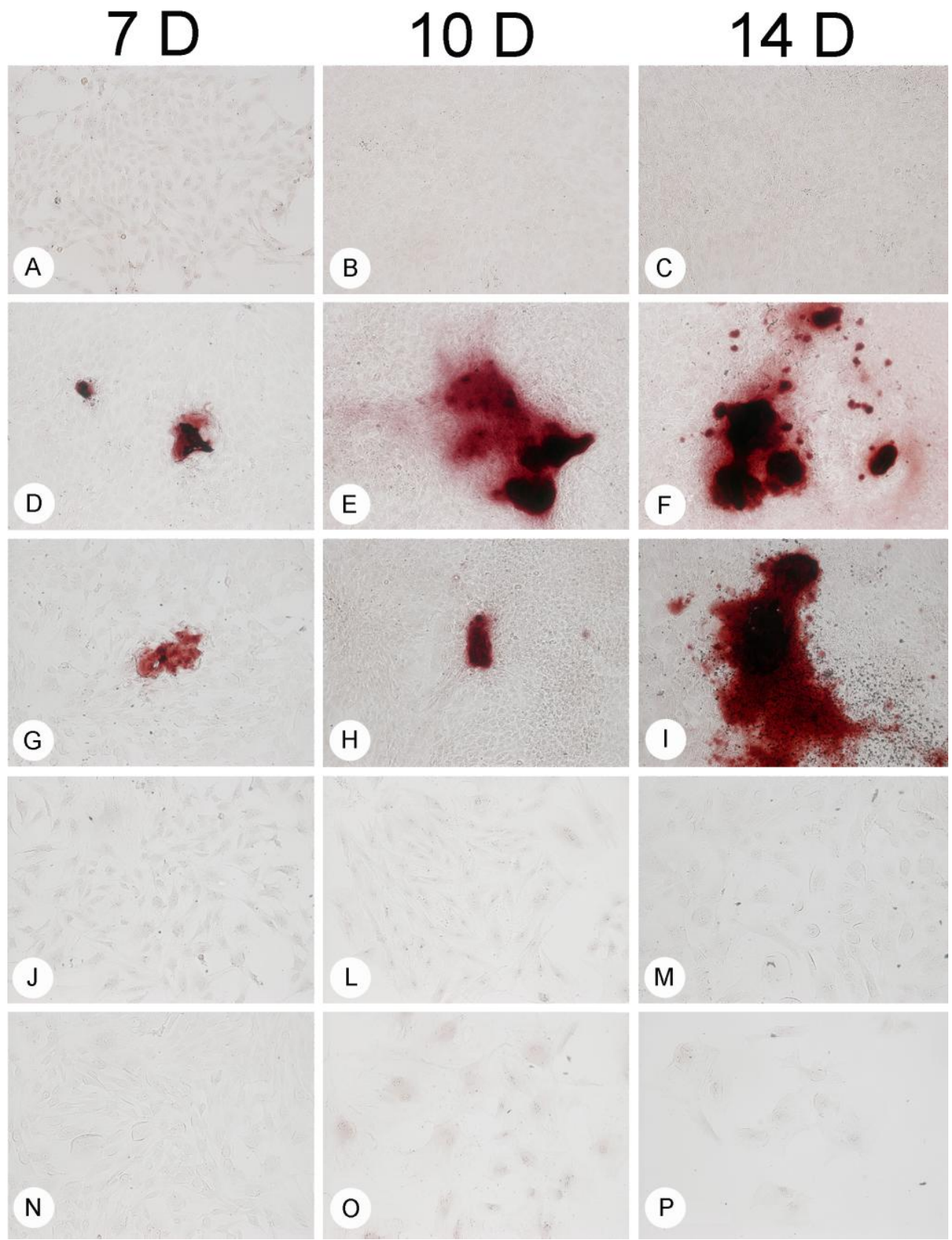

Figura 7: Histoquímica - Vermelho de Alizarina. Os nódulos minerais (corados intensamente em vermelho) foram vistos somente no controle positivo de mineralização (D-F) e no grupo tratado com Dex (G-I). Os demais tratamentos: TGF $\beta 1$ (J-M) e TGF $\beta 1+$ Dex (N-P), assim como o controle negativo de mineralização $(A-C)$, não formaram nódulos minerais e tiveram a sua confluência diminuída. 
evidenciando em preto, o fosfato contido nos nódulos de mineral; esse resultado se repetiu quando as células foram tratadas com Dex (Fig. 8 G-I).

As células tratadas com TGF $\beta 1$, acrescidas ou não com Dex, não formaram nódulos de minerais, sendo von Kossa negativo. Além disso, com o decorrer dos tempos experimentais, houve uma diminuição notória no número celular desses grupos (Fig. 8 J-M e N-P).

\subsubsection{Imunofluorêscencia}

As imunofluorêscencias foram utilizadas para analisar a presença das proteínas: OPN, BSP e FN, nas células osteogênicas cultivadas e, dessa maneira, certificar esse fenótipo nas células. A análise foi feita após 4 dias de tratamento. A substituição do anticorpo $1^{\text {áro }}$ por PBS foi usada como controle negativo para reação (Fig 9-11 A).

\section{a) Osteopontina (OPN)}

A marcação da OPN observada foi mais intensa na região perinuclear (região correspondente ao Golgi), apresentando uma marcação pontuada ao longo do citoplasma. As células que não receberam tratamento foram OPN negativas (Fig. 9 $B)$, entretanto as que receberam algum tipo de tratamento, incluindo com TGF $\beta$, imunoexpressaram essa proteína (Fig. 9 C-D).

\section{b) Sialoproteína óssea (BSP)}

A BSP foi detectada distintamente na região do Golgi e ao longo do citoplasma, por uma marcação pontuada. Assim como na OPN, ela também foi imunoexpressa em todas as células osteogênicas tratadas, mesmo as com TGFß1. A marcação para BSP foi negativa, apenas, nas células que não tiveram nenhum tratamento (controle negativo de mineralização) (Fig. 10 B-F).

\section{c) Fibronectina (FN)}

Em geral, em culturas de células, como há o processo de achatamento, alguns filamentos formam uma rede regular, que rodeiam o núcleo e se estendem por todo 
$7 \mathrm{D}$
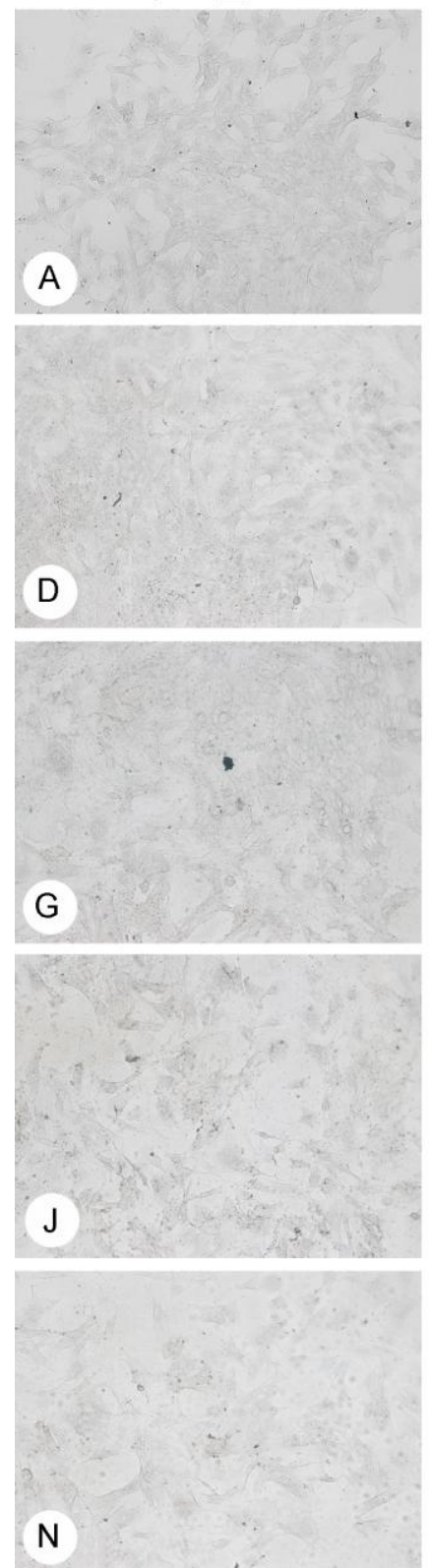

$10 \mathrm{D}$
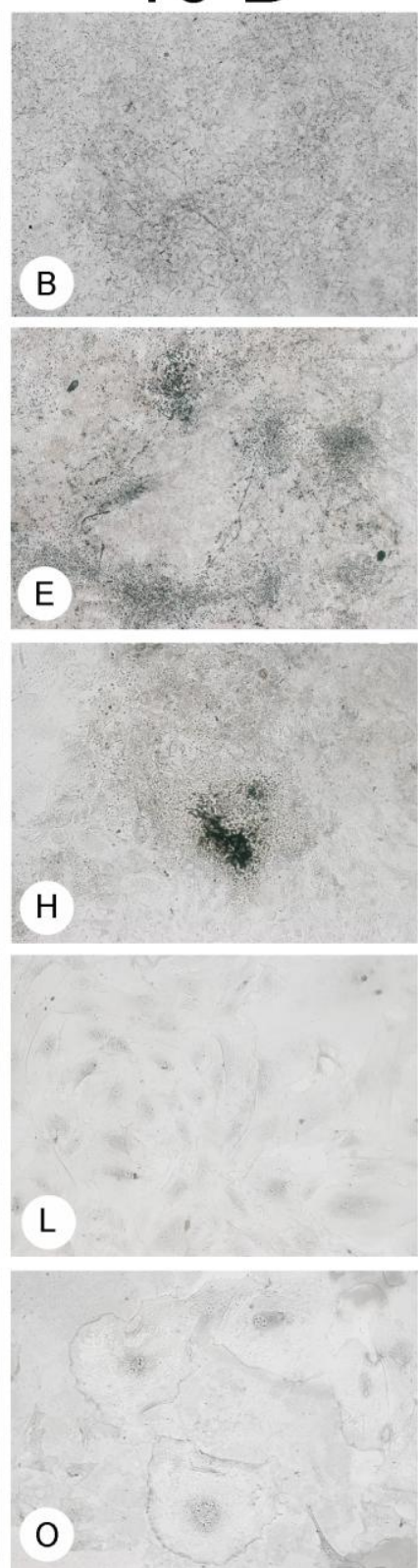

$14 \mathrm{D}$
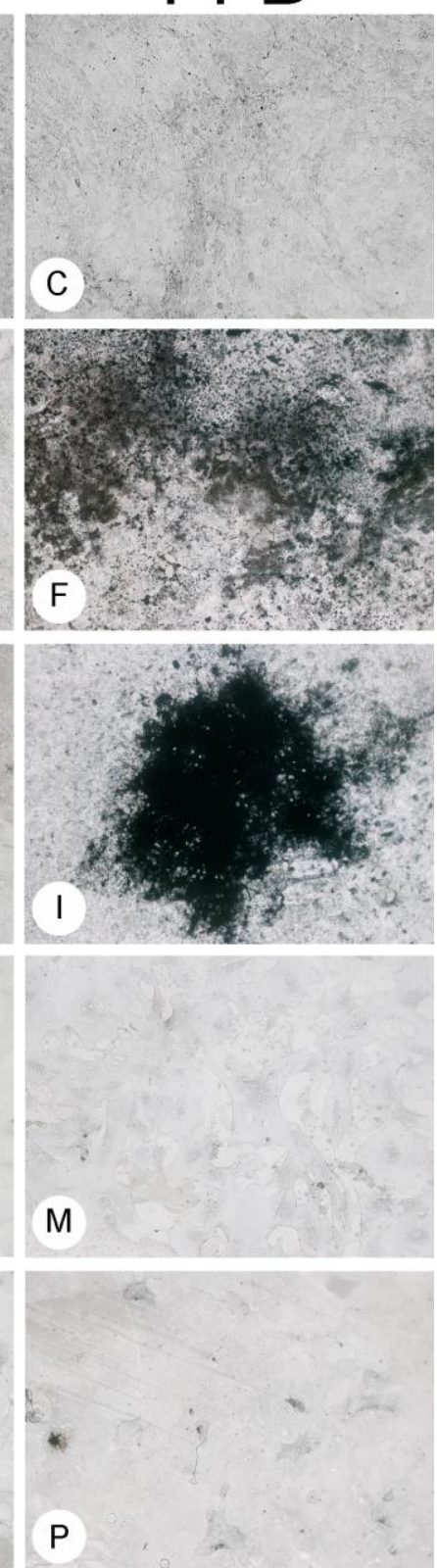

Figura 8: Histoquímica - von Kossa. Os nódulos minerais (corados em preto) foram vistos somente no controle positivo de mineralização (D-F) e no grupo tratado com Dex (G-I). Os demais tratamentos: TGFß1 (J-M) e TGF $\beta 1+D e x(N-P)$ não formaram nódulos minerais assim como o controle negativo de mineralização $(A-C)$ e tiveram a sua confluência diminuída. 

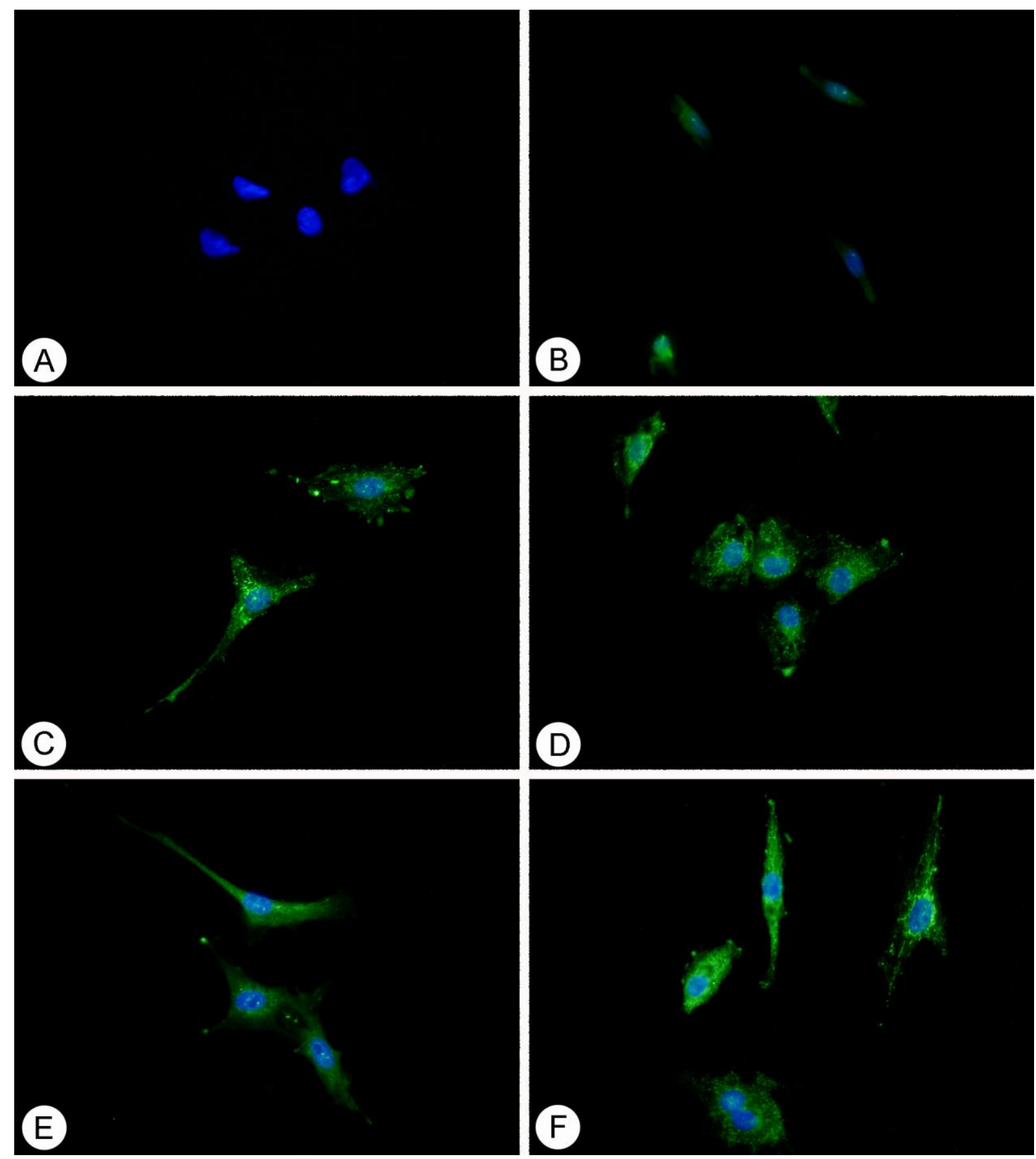

Figura 9: Imunomarcação para OPN (verde) e núcleo (DAPI, azul) em cultura primária de células osteogênicas. (A) Controle negativo da reação; (B) Controle negativo de mineralização; (C) Controle positivo de mineralização; (D) Tratadas com Dex; (E) Tratadas com TGF $\beta 1$; (E) Tratadas com TGF $\beta 1+D e x$. Todos os grupos exceto controle negativo de mineralização foram imunoreativos a OPN, apresentando uma marcação perinuclear intensa - correspondendo a região do complexo de Golgi, diminuindo sua intensidade ao longo do citoplasma. Epifluorescência, aumento de $\mathrm{x} 400$. 


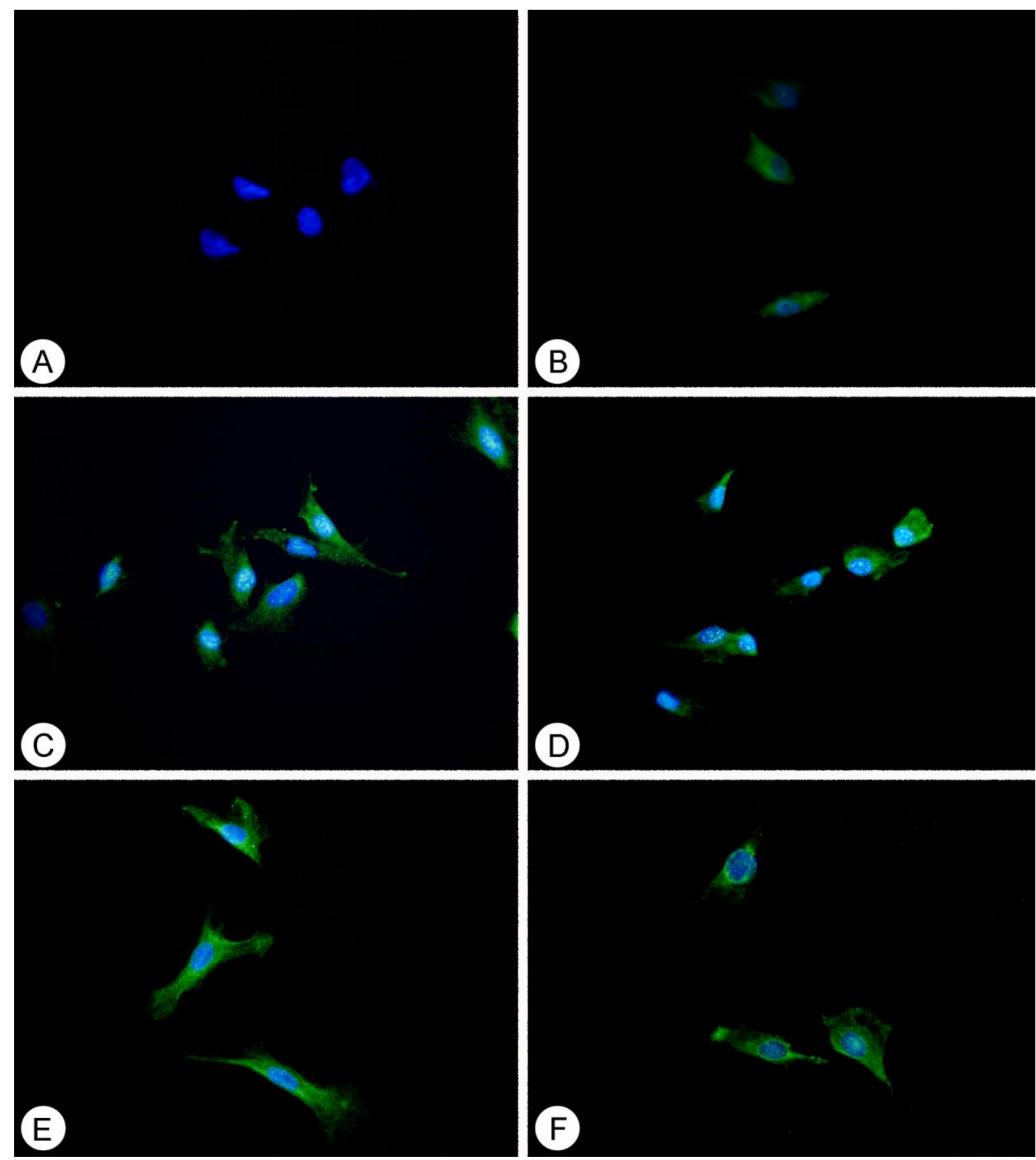

Figura 10: Imunomarcação para BSP (verde) e núcleo (DAPI, azul) em cultura primária de células osteogênicas. (A) Controle negativo da reação; (B) Controle negativo de mineralização; (C) Controle positivo de mineralização; (D) Tratadas com Dex; (E) Tratadas com TGF $\beta 1 ;(F)$ Tratadas com TGF $\beta 1+D e x$. Todos os grupos exceto controle negativo de mineralização foram imunoreativos a BSP, foi detectada distintamente na região do Golgi e ao longo do citoplasma de forma pontuada. Epifluorescência, aumento de x400. 
o citoplasma em forma de lamelipódios. Tais características foram observadas em todos os grupos, incluindo o grupo controle. Desse modo, a FN foi positiva (Fig. 11 B-F). As células do grupo controle negativo (sem tratamento) assemelham-se a fibroblastos, são fusiformes, com núcleo elíptico, distinguindo-se morfologicamente dos demais grupos (Fig $11 \mathrm{~B}-\mathrm{F}$ ).

\subsection{Análise da morfologia celular}

A cultura que não teve nenhum tratamento (controle negativo) apresentou células tipicamente fibroblásticas, com formato fusiforme, núcleo elíptico com cromatina frouxa e um amplo citoplasma, rico em organelas de síntese e secreção de proteínas bem desenvolvidas, como retículo endoplasmático rugoso e complexo de Golgi, além de inúmeras mitocôndrias. Apesar de toda essa maquinaria intracelular, foi observada uma MEC pobre, com algumas fibrilas colágenas entre as células nos dois períodos estudados (Fig. 12 A-C).

Quando essas células tiveram o acréscimo de $A A+\beta G P$ (controle positivo de mineralização), mantiveram as mesmas características morfológicas das células do controle negativo - abundante retículo endoplasmático rugoso e complexo de Golgi bem desenvolvido. Porém, a MEC apresentou-se rica em fibrilas colágenas (Fig. 13 B-C). Nesse período, foi freqüente o encontro de células fazendo contato intercelular, uma vez que as células osteogênicas com 10 dias de cultivos estão dispostas em multicamadas (Fig. 13 A).

Nesse período ainda, foram vistas na MEC algumas áreas iniciando a mineralização, caracterizadas pela nucleação dos cristais de HA entre as fibrilas colágenas (Fig. $14 \mathrm{~A}$ ). Ao $14^{\circ}$ dia de tratamento, são evidentes os abundantes nódulos minerais na MEC, entre as células (Fig. 14 B-C). Esses resultados confirmaram as marcações histoquímicas com vermelho de alizarina e von Kossa, excluindo a hipótese de precipitados de corante artefatuais.

As células que tiveram o acréscimo de Dex no meio de cultura usado como controle positivo, bem como as tratadas apenas com esse, mantiveram a mesmas características morfológicas (Fig. 15 A). Além disso, também formaram nódulos minerais, porém foram vistos algumas vezes entre as poucas fibrilas colágenas - 

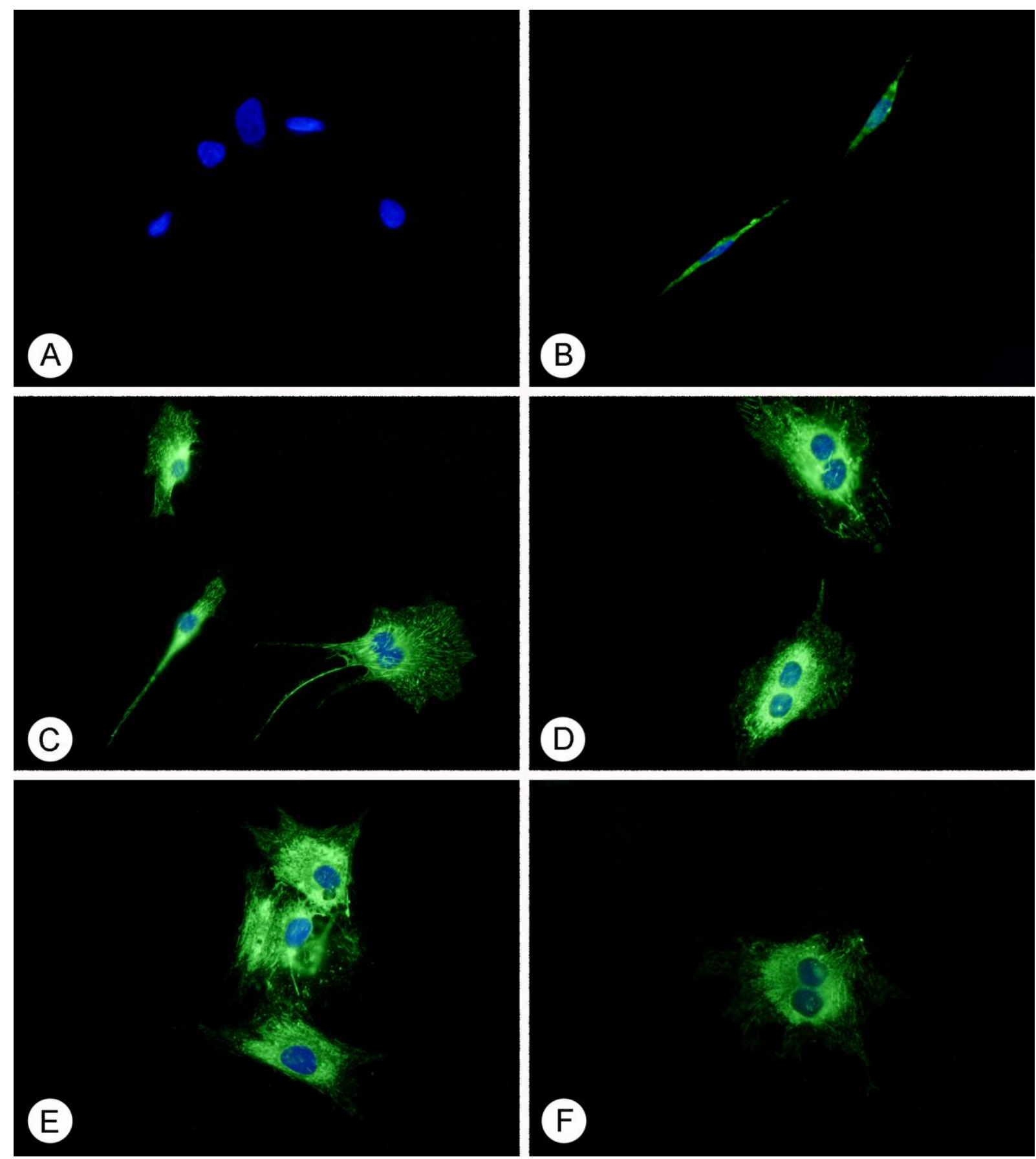

Figura 11: Imunomarcação para FN (verde) e núcleo (DAPI, azul) em cultura primária de células osteogênicas. (A) Controle negativo da reação; (B) Controle negativo de mineralização; (C) Controle positivo de mineralização; (D) Tratadas com Dex; (E) Tratadas com TGF $\beta$; (E) Tratadas com TGF $\beta+D e x$. A marcação para FN foi expressa em todos os tratamentos, inclusive no controle negativo de mineralização. Epifluorescência, aumento de x400. 

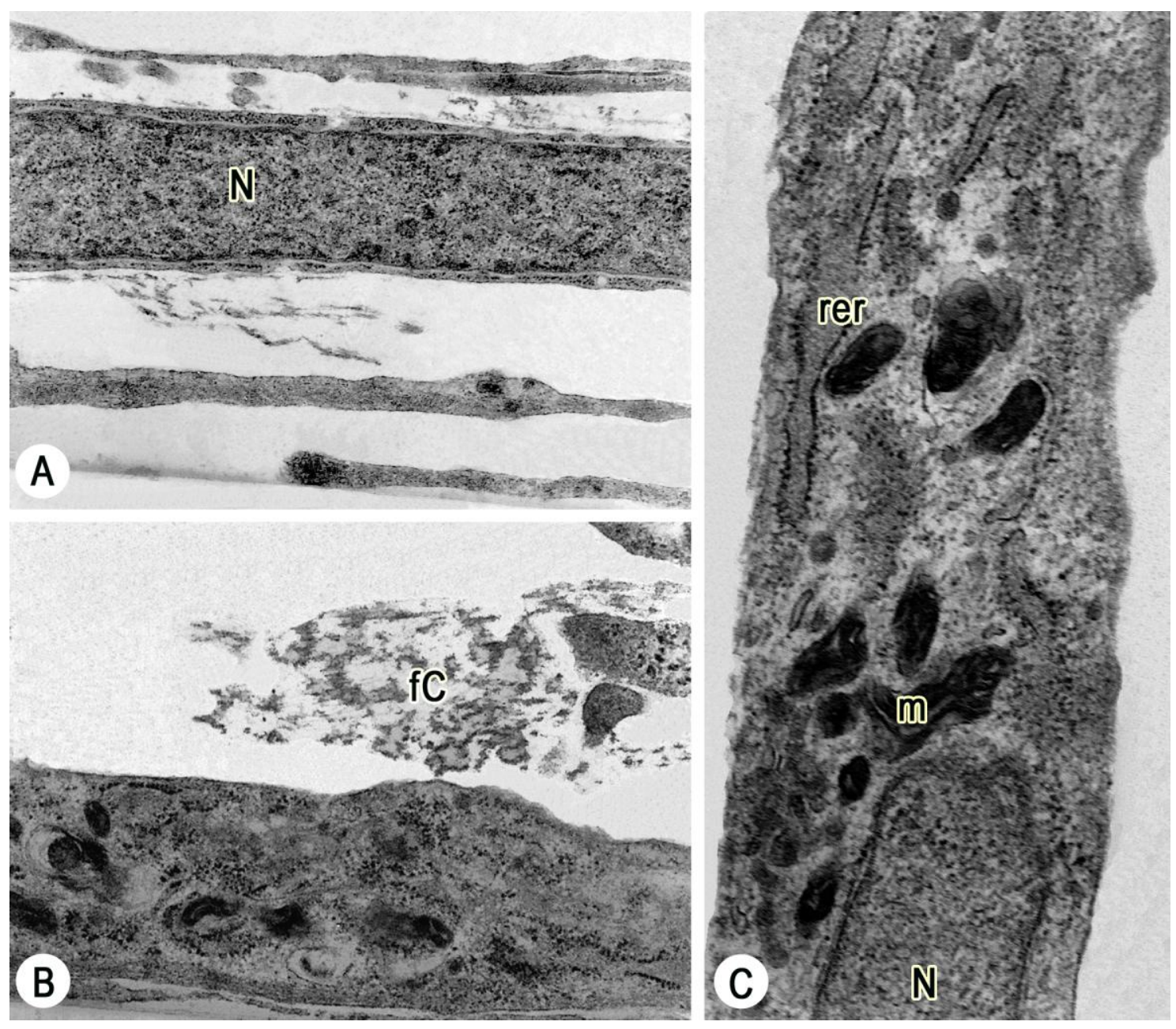

Figura 12: Controle negativo de mineralização. Micrografias eletrônicas de transmissão de células osteogênicas sem tratamento - (A-B) 10 dias e (C) 14 dias. (A) Observa-se o núcleo $(\mathrm{N})$ e prolongamentos celulares (seta); (B) Parte do citoplasma e uma pequena região de matriz extracelular, rica em fibrilas de colágeno (fC); (C) Parte de uma célula osteogênica, mostrando um citoplasma rico em organelas como: mitocôndrias $(\mathrm{m})$ e retículo endoplasmático rugoso (rer) e parte do núcleo $(\mathrm{N})$. Aumentos: A- 22500x, B- 32000x, C- 37500x. 


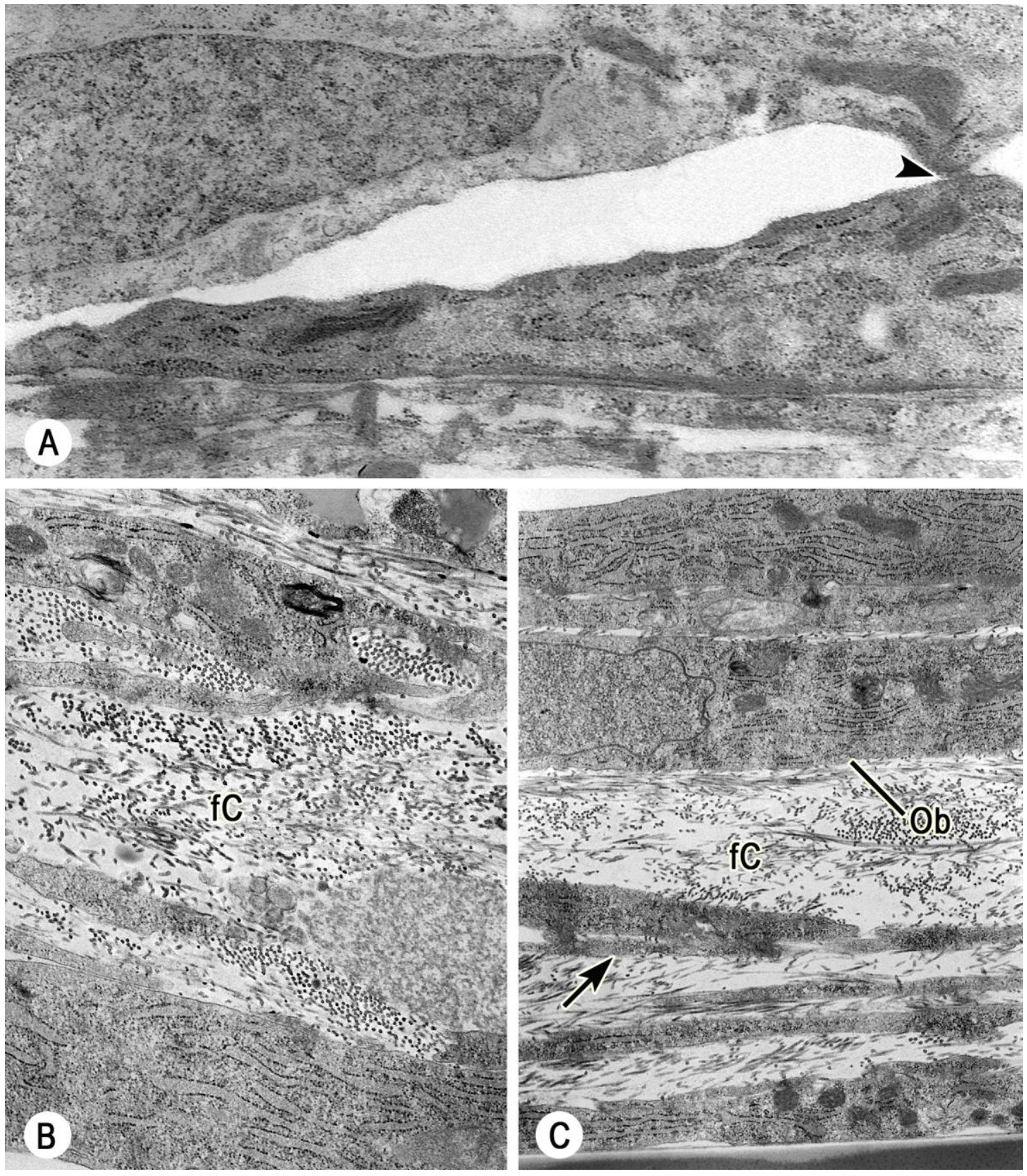

Figura 13: Controle positivo de mineralização. Micrografias eletrônicas de transmissão de células osteogênicas tratadas com $A A+\beta G P-(A-C) 10$ dias. (A) Células estabelecendo contato intercelular (cabeça de seta); (B) Matriz extracelular rica em fibrilas de colágeno ( $\mathrm{fC}$ ) entre células osteogênicas; (C) Parte de um osteoblasto $(\mathrm{Ob})$ e alguns prolongamentos celulares (seta) entre fibrilas de colágeno ( $\mathrm{fC}$ ). Aumentos: A- 30000x, B- 20000x, C-15600x. 

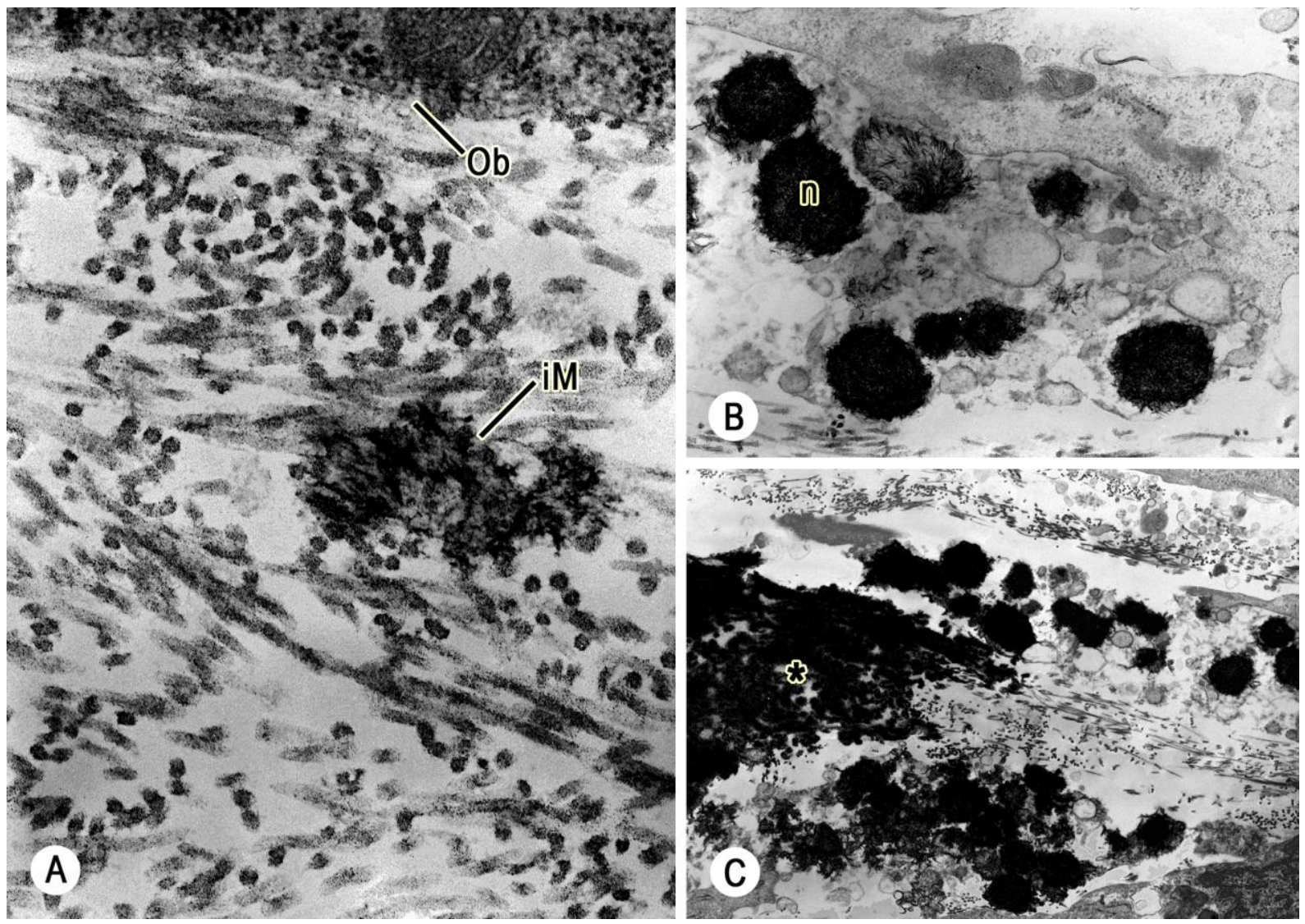

Figura 14: Controle positivo de mineralização. Micrografias eletrônicas de transmissão de células osteogênicas tratadas com $A A+\beta G P-(A) 10$ dias e (B-C) 14 dias. (A) Início da mineralização (iM) - nucleação dos primeiros cristais de hidroxiapatita e parte de um osteoblasto (Ob) logo a cima; (B) Nódulos minerais (n) entre fibrilas colágeno, próximo a um osteoblasto; (C) Área em estágio avançado de mineralização ( ${ }^{\star}$ ). Aumentos: A- 70000x, B- 20000x, C- 6600x. 
MEC escassa e com mais frequência sobre o Thermanox (lamínula plástica usada como substrato) (Fig. 15 B-C).

Já nas que tiveram o acréscimo de TGF $\beta 1$, a morfologia foi modificada, não apresentando características nem do controle negativo, nem do positivo. Elas apareceram na maioria das vezes: alongadas e afiladas, apresentando em seu interior uma grande quantidade de RER e mitocôndrias. Não foram observados nódulos minerais, nem outros componentes de MEC (Fig. 16 A-B).

Quando foi feita a adição de TGFß1+Dex ao meio base (controle positivo de mineralização), as células mantiveram as características morfológicas das tratadas com TGF $\beta 1$, porém observou-se focos de MEC contendo fibrilas colágenas em algumas regiões (Fig. $17 \mathrm{~A}-\mathrm{B})$. 


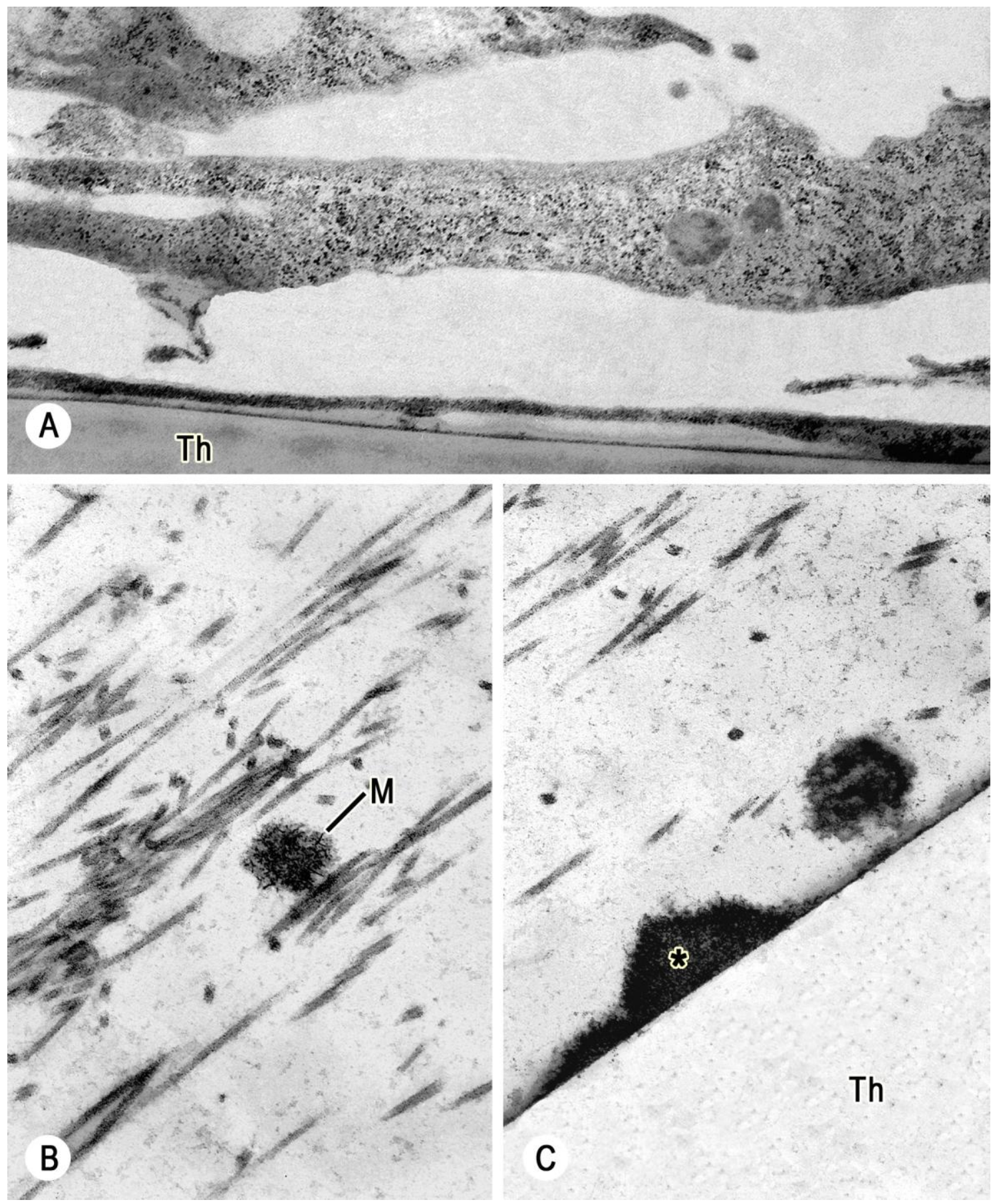

Figura 15: Micrografias eletrônicas de transmissão de células osteogênicas tratadas com Dex (A) 10 dias e (B-C) 14 dias. (A) Prolongamentos celulares sobre Thermanox ${ }^{\circledR}$ (Th); (B) Mineral (M) entre algumas fibrilas de colágeno; (C) Área em estágio avançado de mineralização depositada sobre Thermanox ${ }^{\circledR}\left({ }^{*}\right)$. Aumentos: A- 30000x, B- 56000, C$60000 x$. 

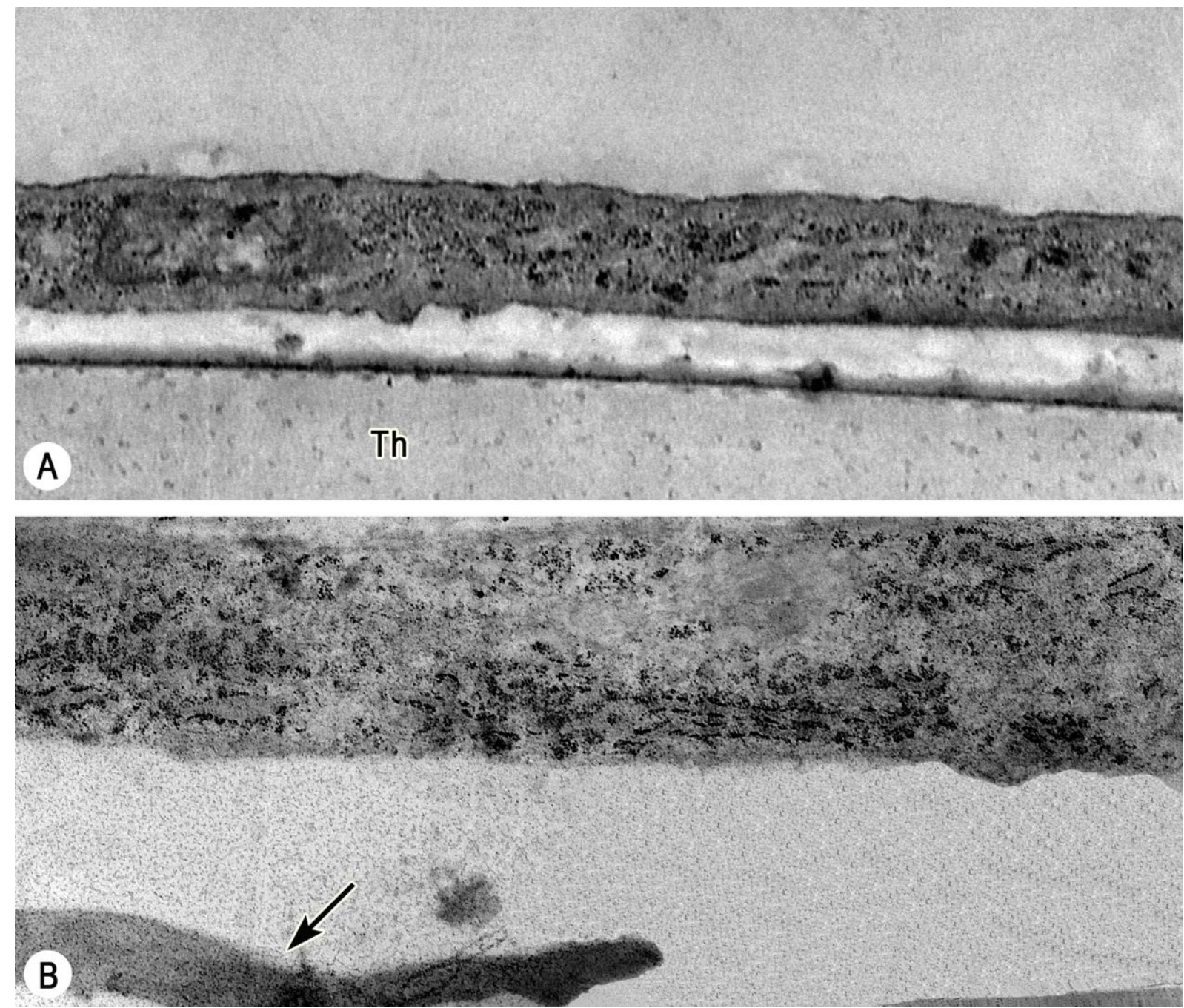

Figura 16: Micrografias eletrônicas de transmissão de células osteogênicas tratadas com TGF $\beta 1$ - (A) 10 dias e (B) 14 dias. (A) Célula alongada e afilada sobre Thermanox ${ }^{\circledR}$ (Th); (B) Prolongamento celular (seta) e parte de um osteoblasto. Aumentos: A- 20000x, B25000x. 

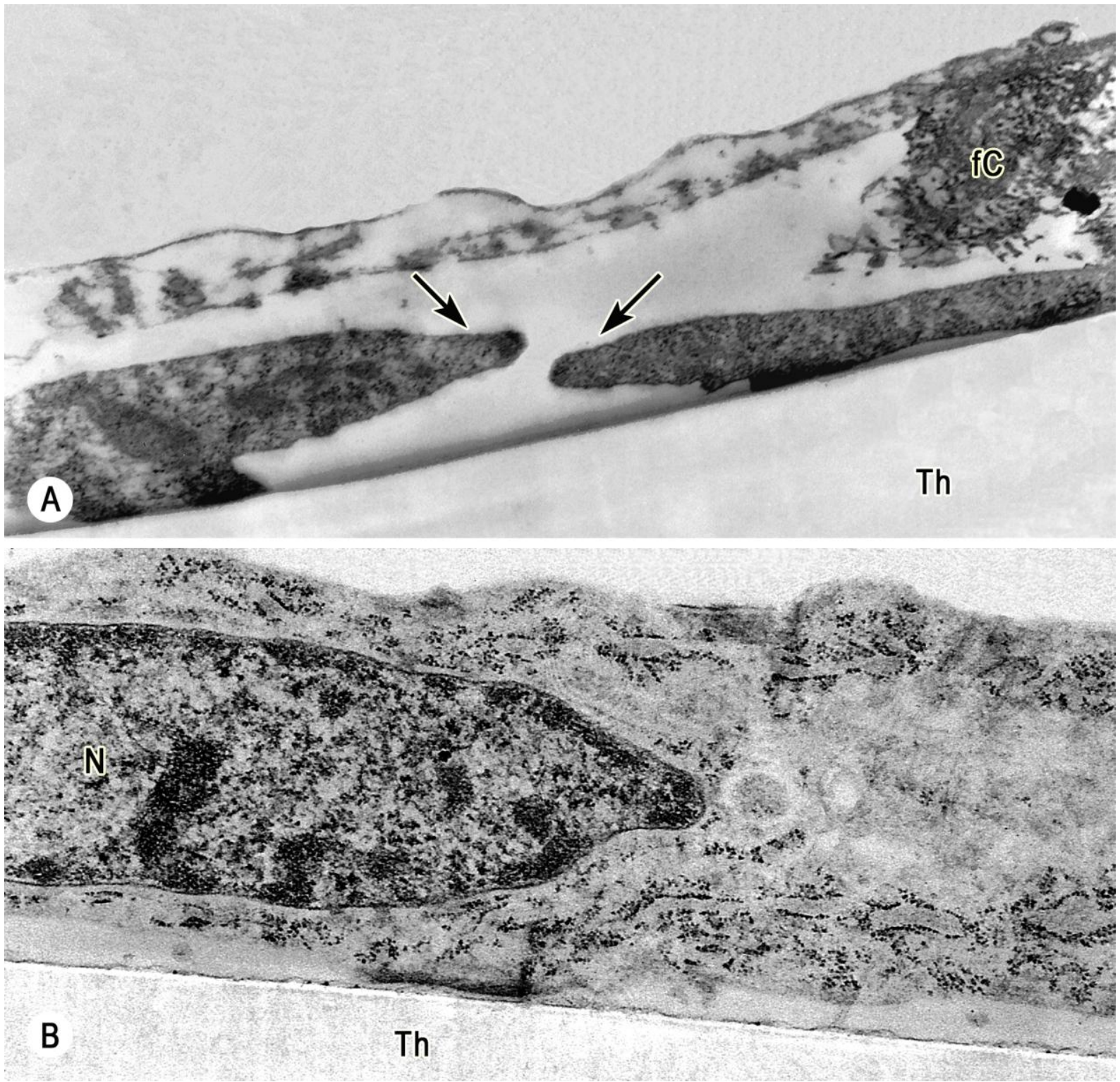

Figura 17: Micrografias eletrônicas de transmissão de células osteogênicas tratadas com TGF $\beta 1+$ Dex - (A) 10 dias e (B) 14 dias. (A) Prolongamentos celulares próximos (setas) e algumas fibrilas de colágeno $(\mathrm{fC})$ sobre Thermanox ${ }^{\circledR}(\mathrm{Th}) ;(B)$ Parte de um osteoblasto sobre o Thermanox ${ }^{\circledR}(\mathrm{Th})$, mostrando o núcleo $(\mathrm{N})$ e o citoplasma, onde podemos observar uma grande quantidade de retículo endoplasmático rugoso (rer). Aumentos: A- 28000x, B- 24000x. 
6 DISCUSSÃO 
Os resultados do presente estudo sugerem que o TGF $\beta 1$ impediu que as células osteogênicas derivadas de calvária de rato formassem nódulos mineralizados in vitro, no entanto, não interferiu na expressão da BSP, proteína não colágena específica de tecidos mineralizados, bem como das proteínas OPN e FN, expressando assim, o fenótipo de osteoblastos diferenciados. A viabilidade celular foi diminuída e o crescimento celular afetado depois que as células foram tratadas com TGF $\beta 1$, administrado sozinho ou combinado com Dex. Esses tratamentos também influenciaram na produção de MEC, apresentando menos fibrilas colágenas e, conseqüentemente, a ausência de nódulos de mineral. A formação de nódulos mineralizados in vitro foi vista apenas nas culturas tratadas com Dex, bem como no controle positivo de mineralização $(A A+\beta G P)$.

O TGF $\beta 1$ é um dos fatores de crescimento mais estudado nos últimos anos, tanto in vitro como in vivo em diversos modelos visando estudos de proliferação e diferenciação celular. Esses estudos revelam que, assim como os glicocorticóides, ele apresenta efeitos paradoxais na diferenciação de células osteoprogenitoras, podendo inibir ou estimular a diferenciação osteoblástica. Isso depende de vários fatores, como: tipo de célula estudada, o estágio de maturação em que as células se encontram quando o tratamento é iniciado, as dosagens e a regularidade das mesmas, bem como as condições em que as culturas se encontram (LIEB et al., 2004).

Diversos glicocorticóides, tais como a corticosterona e a dexametasona, vêm sendo estudados em culturas de células osteogênicas, apesar de, in vitro, apresentarem efeitos contraditórios (ISHIDA e HEERSCHE, 1998; PURPURA et al., 2004). Geralmente, os níveis fisiológicos de glicocorticóides parecem ser necessários para a diferenciação dos osteoblastos; porém, quando esses níveis são altos, os glicocorticóides podem ter efeitos contrários, causando a redução da proliferação das células osteogênicas.

No presente estudo, as células osteogências derivadas de calvária de ratos foram tratadas com o TGF $\beta 1$, com a Dex, e com ambos durante 14 dias. As doses administradas de TGF 1 1 $(5 \mathrm{ng} / \mathrm{mL})$ e Dex $\left(10^{-7} \mathrm{M}\right)$ foram as usadas em vários outros estudos (IBA et al., 1996; LIEB et al., 2004; MARTINEZ et al., 2007). 
As células osteoprogenitoras, quando tratadas somente com TGF $\beta 1$, ou combinado com Dex, tiveram sua viabilidade celular reduzida significantemente, como foi demonstrado no teste de MTT. Já as células tratadas apenas com Dex mantiveram-se viáveis, como as do controle negativo e positivo de mineralização. Além do teste de viabilidade celular, foram feitas contagens celulares, de modo a formar uma curva de crescimento e, dessa maneira, embasar e complementar o teste de viabilidade. Os dados obtidos pela contagem celular coincidiram com os de viabilidade, havendo sido mostrada também uma diminuição significativa no número das células, quando tratadas com TGF $\beta 1$, sozinho ou acompanhado com Dex. Em ambos os testes essa redução foi mais acentuada a partir do $10^{\circ} \mathrm{dia}$.

Para a análise da formação de nódulos de mineral, foram aplicados testes histoquímicos (vermelho de alizarina e von Kossa) e imunofluorescência, para verificar a expressão ou não de proteínas ósseas.

O TGF $\beta 1$ também interferiu na formação de nódulos de mineral, mesmo quando acompanhado da Dex, sendo assim, vermelho de alizarina e von Kossa negativos, o que coincidiu com os resultados do controle negativo de mineralização (células sem suplementos). Foi possível, ainda, observar que, conforme o tempo de tratamento com TGF $\beta 1$ foi aumentando, o número de células com esse tratamento foi diminuindo, o que não aconteceu com os controles negativo e positivo de mineralização, nem com as células tratadas apenas com Dex. Casos semelhantes foram vistos em estudos prévios (IBA et al., 1995; LIEB et al., 2004; CABILING et al., 2007; DE OLIVEIRA et al., 2008), em que a mineralização era inibida quando algum fator de crescimento era acrescentado ao meio de cultura.

Breen et al. (1994) mostraram que o TGF $\beta 1$ inibia o desenvolvimento e a proliferação de células osteoblásticas derivadas de calvária de fetos de ratos. Essas células, normalmente, exibem uma ordem de eventos de progressão: proliferação celular, formação da matriz e sua conseqüente mineralização. Vários autores sugerem que o TGF $\beta 1$ inicia a proliferação, diferenciação e síntese da matriz pelas células ósseas, mas que ele pode estar menos envolvido nas fases finais da osteogênese como, por exemplo, na mineralização (BONEWALD et al., 1992; BREEN et al., 1994; IBA et al., 1995). Em osteoblastos em seu estado normal (in 
vivo), o TGFß1 é altamente expresso durante a fase de proliferação, na sua forma latente (DALLAS et al., 1993).

Quando a Dex, conhecida como indutora da mineralização in vitro por regular positivamente a diferenciação das células osteogênicas (BODEN et al., 1997; TAIRA et al.; 2003; PURPURA et al., 2004), foi adicionada em dose fisiológica, a mineralização da matriz extracelular ocorreu somente nas células que tiveram esse tratamento, mantendo os mesmos padrões de marcação vistos no controle positivo de mineralização $(A A+\beta G P)$ ao longo dos 14 dias de tratamento, sendo, portanto, positiva para vermelho de alizarina e von Kossa. Tal fato sugere que a formação de nódulos de mineral in vitro pode ser regulada por hormônios adicionados ao meio de cultura, nesse caso, por glicocorticóide sintético - a Dex (PURPURA et al., 2004; BELOTI e ROSA, 2005). Apesar do efeito estimulador de mineralização da Dex estar bem documentado em diferentes sistemas de cultura de células, evidências sugerem que ela possa regular a diferenciação positivamente ou negativamente, dependendo do estágio de diferenciação da célula, tornando assim os seus resultados conflitantes (ISHIDA e HEERSCHE, 1998; PURPURA et al., 2004; BELOTI e ROSA, 2005).

Em relação à expressão de proteínas não colágenas, o TGFß1 não interferiu na expressão de OPN, BSP e FN. As células controle negativo (sem tratamento) não expressaram a OPN e a BSP, mas sim a FN. Essa expressão foi analisada qualitativamente, por imunofluorescência no início da proliferação - 4 dias após os tratamentos.

A OPN não foi expressa apenas nas células do controle negativo, uma vez que essas não tiveram nenhum tipo de suplementação no meio de cultura que induzisse a diferenciação. As células OPN positivas sugerem, assim, que houve a maturação dos pré-osteoblastos isolados da calvária de rato em osteoblastos, como sugerido por outros autores (CANDELIERE et al., 2001; de OLIVEIRA et al., 2003). Em cultura, a OPN apresenta uma marcação mais intensa ao redor do núcleo - região do complexo de Golgi, sendo menos evidente ao longo do citoplasma. Esse padrão de marcacão foi reproduzido em todos os tratamentos, independente do TGF $\beta 1$.

Essa proteína tem manifestação oscilante durante toda a diferenciação celular in vitro, sendo a primeira a estar expressa durante o período de proliferação. Após 
esse estágio, os níveis são diminuídos, voltando a aumentar no início da mineralização - nessa etapa ela atinge seu nível máximo, como demonstrado por alguns autores (ZOHAR et al., 1998; DE OLIVEIRA et al., 2003). Estudos in vitro sugerem ainda que, a OPN seja o nucleador dos primeiros cristais de hidroxiapatita (KAZANECKI et al., 2007). A expressão da OPN pode ser modificada por um grande número de hormônios, citocinas e fatores de crescimento, porém o TGFß1não influenciou no presente estudo (SODEK et al., 2000).

A BSP não foi expressa somente no grupo controle negativo - ausência de tratamento, sendo imunorreativa para os demais grupos, nos quais seu padrão de marcação foi observado. A expressão observada da BSP, foi também analisada no início do tratamento - 4 dias; portanto, no início da diferenciação e maturação das células osteogênicas. Alguns trabalhos, como De Oliveira et al. (2007), mostram que essas células, tratadas apenas com $A A+\beta G P$ - tratamento usado como o controle positivo de mineralização - tiveram a BSP e a OPN imunoexpressas em tempos avançados e na presença de mineral. Tal fato faz dessas proteínas não colágenas um marcador específico das células osteoblásticas diferenciadas, e evidencia sua participação na nucleação da hidroxiapatita, bem como na mineralização da matriz extracelular.

Diferentemente da OPN, a BSP é uma proteína não colágena específica de tecidos mineralizados, o que não exclui a sua expressão em outros tecidos em casos patológicos associados a depósitos de cálcio (PÉCHEUR et al., 2002; BELLAHCÈNE et al., 2008; OGATA, 2008). Estudos in vitro têm mostrado que a BSP é responsável pela nucleação dos cristais de hidroxiapatita, e estudos utilizando microscopia eletrônica mostram a sua localização, confirmando que a BSP está associada aos primeiros cristais de mineral (BIANCO et al., 1993). Ela está associada a uma seqüência de diferenciação de osteoblastos in vitro (STEIN e LIAN, 1993; MALAVAL et al., 1999), e apresenta uma marcação perinuclear intensa, distintamente na região do Golgi, e uma marcação puntiforme pelo citoplasma.

Tanto a OPN quanto a BSP são consideradas moléculas multifuncionais da matriz extracelular - por participarem na adesão e migração celular e, principalmente, por regular o depósito de cristais de mineral (McKEE e NANCI 1996; 
FISHER et al., 2001). A expressão de ambas por células osteoblásticas é extremamente variável (MALAVAL et al., 1999), e a não expressão, como aconteceu nas nossas células sem tratamento, sugere que elas poderiam ser somente préosteoblastos e/ou fibroblastos.

A FN foi imunoexpressa em todos os tratamentos, incluindo o controle negativo de mineralização, que para as demais proteínas estudadas foi imunonegativo. Tal fato sugere que as células sem tratamento simplesmente não sofreram diferenciação, mantendo, assim, o pool celular heterogêneo obtido na digestão enzimática das calvárias de ratos. Pode-se notar, ainda, a diferença morfológica entre as células não tratadas e as que receberam tratamento: estas eram fusiformes e alongadas, lembrando fibroblastos, já aquelas apresentaram formas cubóides, similares a osteoblastos. Esses dados corroboram, de certa maneira, o resultado negativo para a BSP; afinal, essa proteína só é imunoexpressa em células de tecidos mineralizados, salvo em algumas patologias. Isso leva à inferência que o controle positivo de mineralização $(A A+\beta G P)$ e as células tratadas com Dex, TGF $\beta 1$ e TGF $\beta 1+D e x$ se diferenciaram em células osteoblásticas, o que não foi visto nas células sem tratamento.

A FN vem sendo demonstrada em regiões iniciais de osteogênese, havendo sido sugerido que ela possa estar envolvida nos primeiros estágios da formação óssea (MOURSI et al., 1996; 1997). Nordahl et al. (1995) mostraram, através de imunolocalização, a associação da FN com fibrilas de colágeno na matriz do osso durante a ossificação endocondral em ratos jovens. Em cultura de osteoblastos derivados de calvária de ratos, a FN é sintetizada por osteoblastos e acumulada na MEC e, assim como o colágeno tipo I, ela está aumentada durante a proliferação e no início da diferenciação, tendo sua síntese bruscamente reduzida quando as células atingem seu estágio maduro (STEIN et al., 1990; WINNARD et al., 1995).

Assim como a OPN, a FN não é uma proteína específica do osso, pois está presente em várias células e tecidos. Ela se assemelha com a OPN e a BSP por apresentarem a seqüência RGD - responsável pela interação com integrinas da superfície celular, o que torna sua principal função a adesão, podendo, também, 
desempenhar a migração e diferenciação celular, bem como a organização tecidual (MOURSI et al., 1996; CAMPBELL, 2008).

No presente estudo o TGF $\beta 1$ e a Dex não interferiram na expressão da FN, apesar de alguns fatores conhecidos por regular a diferenciação dos osteoblastos, tais como os glicocorticóides, o estrógeno, a vitamina D e mesmo o TGF $\beta$, poderem afetar sua expressão e interação com o osteoblasto (BREEN et al., 1994).

Por meio da MET foi analisado se houve ou não alguma modificação ultraestrutural nas células após os tratamentos, além de ser evidenciada a formação de nódulos de mineral em alguns tratamentos, complementando e confirmando, assim, os resultados obtidos com as técnicas histoquímicas.

Assim como nas demais análises, apenas as células tratadas somente com TGFß1, ou acompanhado de Dex, foram as que sofreram algum tipo de alteração morfológica. A não confluência e a baixa síntese de MEC dos grupos TGFß1 e TGF $\beta 1+$ Dex dificultaram o encontro de áreas com presença de material - células e fibrilas de colágeno não foram observadas com tanta freqüência como nos outros grupos. As células que tiveram esses dois tratamentos eram diferentes morfologicamente das células do controle negativo e positivo. Quando encontradas, se mostraram muito alongadas e afiladas, apresentando no citoplasma algumas organelas, como retículo endoplasmático rugoso e mitocôndrias. Não foi possível observar uma região de MEC entre as células tratadas com TGF $\beta 1$, mas pequenas áreas com fibrilas de colágeno foram vistas, em havendo presença da Dex. As mudanças na morfologia celular podem estar diretamente associadas às alterações no ambiente extracelular, como foi observado nessa e em outras culturas de células (BREEN et al., 1994).

Por outro lado, as células sem tratamento, usadas como controle negativo de mineralização, apresentaram uma morfologia típica de células em alta atividade de síntese, com um citoplasma rico em retículo endoplasmático rugoso, complexo de Golgi e mitocôndrias. Entretanto, foram vistas algumas fibrilas de colágeno entre as células, não apresentando sinais de mineralização em nenhum dos períodos estudados. O controle positivo, que teve o acréscimo de $A A+\beta G P$, apresentou células morfologicamente iguais às do controle negativo de mineralização que, 
diferentemente dele, apresentou uma MEC rica em fibrilas de colágeno, apresentando, em alguns períodos, nódulos de mineral e áreas já em estágio avançado de mineralização. As células tratadas apenas com Dex apresentaram uma morfologia semelhante às células do controle negativo e positivo de mineralização e, apesar da presença de nódulos de mineral, como no controle positivo, eles foram vistos entre uma pequena quantidade de fibras de colágeno e, na maioria das vezes, depositados sobre a lamínula de Thermanox $^{\circledR}$, usada como substrato para as células. Isso sugere que a deposição dos nódulos nas culturas de células que foram tratadas com Dex não é derivada da mineralização da matriz, mas devida à nucleação espontânea, reforçando a idéia de alguns autores de evitarem a adição da Dex com o intuito de induzir a diferenciação osteoblástica.

Sendo assim, os resultados apresentados mostraram que o TGF $\beta 1$ não impediu que as células osteogênicas imunoexpressassem proteínas relacionadas ao desenvolvimento do osso, como foi explicitado, mas que ele alterou a morfologia dessas células, influenciando, de alguma maneira, na redução da síntese da MEC, além de diminuir significativamente a viabilidade e o número celular dos grupos que tiveram esse tratamento, seja sozinho ou acompanhado da Dex. 
7 CONCLUSÕES 
Os resultados do presente estudo permitem concluir que o TGF $\beta 1$ :

- Diminuiu a viabilidade e o número de células osteogênicas com o decorrer do tratamento;

- Interferiu na mineralização in vitro, mesmo na presença de Dex;

- Não alterou a expressão das proteínas estudadas, OPN, BSP e FN, no desenvolvimento ósseo in vitro;

- Alterou a morfologia das células osteogênicas, influenciando na redução da síntese de colágeno e outros componentes da MEC. 


\section{REFERÊNCIAS}


ABU, E. O.; HOMER, A.; KUSEC, V.; TRIFFITT, J. T.; COMPSTON, J. E. The localization of the functional glucocorticoid receptor alpha in human bone. $\mathbf{J}$ Clin Endocrinol. Metab., v. 85, p. 883-889, 2000.

ALFORD, A. I.; HANKENSON, K. D. Matricellular proteins: extracellular modulators of bone development, remodeling, and regeneration. Bone, v. 38, p. 749-757, 2006.

ARANA-CHAVEZ, V. E.; BRADASCHIA-CORREA, V. Clastic cells: mineralized tissue resorption in health and disease. Int. J. Biochem. Cell. Biol., v. 41, p. 446450, 2009.

ASOU, Y.; RIRRLING, S. R.; YOSHITAKE, H.; TSUJI, K.; SHINOMIVA, K.; NIFUJI, A.; DENHARDT, D.T.; NODA, M. Osteopontin facilitates angiogenesis, accumulation of osteoclasts, and resorption in ectopic bone. Endocrinology, v. 142, p. 1325-1332, 2001.

BELLAHCÈNE, A.; CASTRONOVO, V.; OGBUREKE, K. U.; FISHER, L. W.; FEDARKO, N. S. Small intergrin-binding ligand N-linked glycoproteins (SIBLINGs): multifunctional proteins in cancer. Nat. Rev. Cancer, v. 8, p. 212-226, 2008.

BELLOWS, C. G.; AUBIN, J. E. Determination of numbers of osteoprogenitors present in isolated fetal rat calvaria cells in vitro. Dev. Biol., v. 133, p. 8-13, 1989.

BELLOWS, C. G.; AUBIN, J. E.; HEERCHE, J. N. Initiation and progression of mineralization of bone nodules formed in vitro: the role of alkaline phosphatase and organic phosphate. Bone Miner., v. 14, p. 27-40, 1991.

BELLOWS, C. G.; HEERSCHE, J. N.; AUBIN J. E. Inorganic phosphate added exogenously or released from beta-glycerophosphate intiates mineralization of osteoid nodules in vivo. Bone Miner., v. 17, p. 15-29, 1992.

BELLOWS, C. G.; SODEK, J.; YAO, K. L.; AUBIN, J.E. Phenotypic differences in subclones and long-term cultures of clonally derived rat bone cells line. J. Cell Biomechem., v. 31, p. 153-169, 1986.

BELOTI, M. M.; ROSA, A. L. Osteoblast differentiation of human bone marrow cells under continuous and discontinuous treatment with dexamethasone. Braz. Dent. J., v. 16, p. 156-161, 2005.

BIANCO, P.; FISHER, L. W.; YOPUNG, M. F.; TERMINE, J. D.; ROBEY, P. G. Expression of bone sialoprotein (BSP) in developing human tissues. Calcif. Tissue Int., v. 49, p. 421-426, 1991.

BIANCO, P.; RIMINUCCI, M.; SILVESTRINI, G.; BONUCCI, E.; TERMINE, J. D.; FISHER, L. W.; ROBEY, P. G. Localization of bone sialoprotein (BSP) to golgi and post-Golgi secretory structures in osteoblasts and to discrete sites in early bone matrix. J. Histochem. Cytochem., v. 41, p. 193-203, 1993. 
BODEN, S. D.; HAIR, G.; TITUS, L.; RACINE, M.; McCUAIG, K.; WOZNEY, J. D.; NANES, M. S. Glucocorticoid-induced differentiation of fetal rat calvarial osteoblasts is mediated by bone morphogentic protein-6. Endocrinoloy, v. 138, p. 2820-2828, 1997.

BONEWALD, L. F.; DALLAS, S. L. Role of active and latent transforming growth factor beta in bone formation. J.Cell Biochem., v. 55, p. 350-357, 1994.

BONEWALD, L. F.; KESTER, M. B.; SCHWARTZ, Z.; SWAIN, L. D.; KHARE, A.; JOHNSON, T. L.; LEACH, R. J., BOYAN, B. D. Effects of combining transforming growth factor beta and 1,25-dihydroxyvitamin D3 on differentiation of a human osteosarcoma (MG-63). J. Biol. Chem., v. 267, p. 8943-8949, 1992.

BREEN, E. C.; IGNOTZ, R. A.; McCABE, L.; STEIN, J. L.; STEIN, G. S.; LIAN, J. B. TGF- $\beta$ alters growth and differentiation related gene expression in proliferating osteoblasts in vitro, preventing development of mature bone phenotype. J. Cell Physiol., v. 160, p. 323-335, 1994.

CABILING, D. S; KIM, E.; YAN, D.; JACOB, S.; NAH, H. D.; KIRSCHNER, R.E. Differential effects of TGF-beta isoforms on murine fetal dural cells and calvarial osteoblasts. Plast. Reconstr. Surg., v. 120, p. 614-624, 2007.

CAMPBELL, I. D. Studies of focal adhesion assembly. Biochem. Soc. Trans., v. 36, p. 263-266, 2008.

CANALIS, E. Mechanisms of glucocorticoid action in bone: implications for glucocorticoid-induced osteoporosis. J. Clin. Endocrinol. Metab., v. 81, p. 34413447, 1996.

CANALIS, E.; McCARTHY, T.L.; CENTRELLA, M. Growth factors and cytokines in bone cell metabolism. Annu. Rev. Med., v. 42, p. 17-24, 1991.

CANALIS, E.; PASH, J.; VARGHESE, S. Skeletal growth factors. Crit. Rev. Eukaryol. Gene Expr., v. 3, p. 155-166, 1993.

CANDAELIERE, G. A.; LIU, F.; AUBIN, J. E. Individual osteoblasts in the developing calvaria express different gene repertoires. Bone, v. 28, p. 351-361, 2001.

CENTRELLA, M.; McCARTHY, T.L.; CANALIS, E. Skeletal tissue and transforming growth factor beta. FASEB J., v. 2, p. 3066-3073, 1988.

CENTRELLA, M.; HOROWITZ, M.C.; WOZNEY, J.M.; McCARTHY, T.L. Transforming growth factor-beta gene family members and bone. Endocr. Rev., v. 15, 27-39, 1994.

CENTRELLA, M.; JI, C.; McCARTHY, T. L. Control of TGF-beta receptor expresión in bone. Front. Biosci., v. 15, p. 113-124, 1998. 
CHIQUET-EHRISMANN, R. Tenascin a growing family of extracellular matrix proteins. Experientia, Basel, v. 51, p. 853-862, 1995.

COUBLE, M. L.; FARGES, J. C.; BLEICHER, F.; PERRAT-MABILLON, B.; BOUDELLE, M.; MAGLOIRE, H. Odontoblast differentiation of human dental pulp cells in explant cultures. Calcif Tissue Int., v. 66, p. 129-138, 2000.

COUSSENS, A. K.; HUGHES, I. P.; MORRIS, C. P.; POWELL, B. C.; ANDERSON, $P$. J. In vitro differentiation of human calvarial suture derived cells with and without dexamethasone does not induce in vivo-like expression. J. Cell Physiol., v. 218, p. 183-191, 2009.

DALLAS, S. L.; PARK-SNYDER, S.; MAKUSKY, A. J.; MUNDY, G. R.; MIYAZOHO, K.; BONEWALD, L. F. Proliferating fetal rat calvarial cells produce distinctly different formas of latent transforming growth factor beta (TGF $\beta$ ) compared to mineralizing cells. J. Bone Min. Res., v. 8, p. S306, 1993.

DE ARCANGELIS, A.; GEORGES-LABOUESSE, E. Integrin and ECM functions: role in vertebrate development. Trends Genet., v. 16, p. 389-95, 2000.

DELAISSE, J. M.; ANDERSEN, T. L.; ENGSIG, M. T.; HENRIKSEN, K.; TROEN, T.; BLAVIER, L. Matrix metalloproteinases (MMP) and cathein $\mathrm{K}$ contribute differently to osteoclastic activities. Microsc. Res. Tech., v. 61, p. 504-513, 2003.

DENHARDT, D. T.; GUO, X. Osteopontin: a protein with diverse functions. FASEB J., v. 7, p. 1475-1482, 1993.

DENHARDT, D. T.; NODA, M.; O'REGAN, A. W.; PAVLIN, D.; BERMAN, J. S. Osteopontin as a means to cope with environmental insults: regulation of inflammation tissue remodeling, and cell survival. J. Clin Invest., v. 107, p. 10551061, 2001a.

DENHARDT, D. T.; GIACHELLI, C. M.; RITTLING, S. R. Role of osteopontin in cellular signaling and toxicant injury. Annu. Rev. Pharmacol. Toxicol., v. 41, p. 723749, 2001b.

DE OlIVEIRA, P. T.; OLIVA, M. A.; MAXIMIANO, W. M. A.; SEBASTIÃO, K. E. V.; CRIPPA, G. E.; CIANCAGLINI, P.; BELOTI, M. M.; NANCI, A.; ROSA, A. L. Effects of a mixture of growth factors and proteins on the development of the osteogenic phenotype in human alveolar bone cell cultures. J. Histochem. Cytochem., v. 56, p. 629-638, 2008.

DE OLIVEIRA, P. T.; ZALZAL, S.F.; BELOTI, M. M.; ROSA, A. L.; NANCI, A. Enhancement of in vintro osteogenesis on titanium by chemically produced nanotopograhy. J. Biomed. Mater. Res. A., v. 80, p. 554-564, 2007. 
DE OLIVEIRA, P. T.; ZALZAL, S. F.; IRIE, K.; NANCI, A.Early expression of bone matrix proteins in osteogenic cell cultures. J. Histochem. Cytochem., v. 51, p. 633641, 2003.

DONATO, T. A. G.; ALMEIDA, L. H.; NOGUEIRA, R. A.; NIEMEYER, T. C.; GRANDINI, C. R.; CARAM, R.; SCHNEIDER, S. G.; SANTOS JUNIOR, A. R. Citotoxicity study of some ti alloys used as biomaterial. Mater. Sci. Eng. C, v. 29, p.1365-1369, 2009.

ESPINA, B.; LIANG, M.; RUSSELL, R. G.; HULLEY, P. A. Regulation of bim in glucocorticoid mediated osteoblast apoptosis. J. Cell Physiol., v. 215, p. 488-96, 2008.

FARALLI, J. A.; SCHWINN, M. K.; GONZALEZ, J. M. Jr; FILLA, M. S.; PETERS, D. M. Functional properties of fibronectin in the trabecular meshwork. Exp. Eye Res., v. 88, p. 689-693, 2009.

FISHER, L. W.; FEDARKO, N. S. Six genes expressed in bones and teeth encode the current members of the SIBLING family of proteins. Connect. Tissue Res., v. 44, p. 33-40, 2003, Suppl.

FISHER, L. W.; McBRIDE, O. W.; TERMINE, J. D.; YOUNG, M. F. Human bone sialoprotein. Deduced protein sequence and chromosomal localization. J. Biol. Chem., v. 265, p. 2347-2351, 1990.

FISHER, L. W.; TORCHIA, D. A.; FOHR, B.; YOUNG, M.F.; FEDARKO, N. S. Flexible structures of SIBLING proteins, bone sialoprotein, and osteopontin. Biochem. Biophy. Res. Commun., v. 280, p. 460-465, 2001.

FRANCESCHI, R. T. The role of ascorbic acid in mesenchymal differentiation. Nutr. Rev., v. 50, p. 65-70, 1992.

FRANCESCHI, R. T.; IYER, B. S. Relationship between collagen synthesis and expression of the osteoblast phenotype in MC3T3-E1 cells. J. Bone Miner. Res., v. 7, p.235-246, 1992.

FRANZ-ODENADAAL, T. A.; HALL, B. K.; WITTEN, P. E. Buried alive: How osteoblast become osteocytes. Dev. Dyn., v. 235, p. 176-190, 2006.

FUJISAWA, R.; BUTLER, W. T.; BRUNN, J. C.; ZHOU, H. Y.; KUBOKI, Y. Differences in composition of cell-attachment sialoproteins between dentin and bone. J. Dent. Res., v. 72, p. 1222-1226, 1993.

GANSS, B.; KIM, R. H.; SODEK, J. Bone sialoprotein. Crit. Rev. Oral Biol. Med., v. 10; p. 79-98, 1999. 
GLOBUS, R. K.; DOTY, D. B.; LULL, J.C.; HOLMUHAMEDOV, E.; HUMPHRIES, M. J.; DAMSKY, C. H. Fribronectin is survival factor for differentiated osteoblasts. J. Cell Sci., v. 111, p. 1385-1393, 1998.

GOLDBERG, H. A.; WARNER, K. J., STILLMAN, M. J.; HUNTER, G. K. Determination of the hydroxyapatite-nucleating region of bone sialoprotein. Connect. Tissue Res., v. 35, p. 385-392, 1996.

HARADA, S.; RODAN G. A. Control of osteoblast function and regulation of bone mass. Nature, v. 423, p. 349-356, 2003.

HAYLOCK, D. N.; NILSSON, S. K. Osteopontin: a bridge between bone and blood. Br. J. Haematol., v. 134, p. 467-474, 2006.

HERPIN, A.; LELONG, C.; FAVREL, P. Transforming growth factor- $\beta$-related proteins: an ancestral and widespread superfamily of cytokines in metazoans. Dev. Comp. Immunol. 28, p. 461-485, 2004.

HIRASHITA, A. The aspect of ultrastructural changes of the osteoblasts and surface areas of alveolar bone appearing in experimental tooth movement. Bull. Tokyo Med. Univ., v.23, p. 245-260, 1976.

HU, D. D.; LIN, E. C.; KOVACH, N. L.; HOYER, J. R.; SMITH, J. W. A biochemical characterization of the binding of osteopontin to integrins alpha $v$ beta 1 and alpha $v$ beta 5. J. Biol. Chem., v. 270, p. 26232-26238, 1995.

HUGHES, F. J.; COLLYER, J.; STAINFIELD, M.; GOODMAN, S. A. The effects of bone morphogenetic protein-2, -4 and -6 on differentiation of rat osteoblast cells in vitro. Endocrinology, v. 136, p. 2671-2677, 1995.

HUNTER, G. K.; GOLDBERG, H. A. Modulation of crystal formation by bone phosphoproteins: role of glutamic acid-rich sequences in the nucleation of hydroxyapatite by bone sialoprotein. Biochem. J., v. 15, p. 175-179, 1994.

HUNTER, G. K.; KYLE, C. L.; GOLDBERG, H. A. Modulation of crystal formation by bone phosphoproteins: structural specificity of the osteopontin-mediated inhibition of hydroxyapatite formation. Biochem. Pharmacol., v. 300, p. 723-728, 1994.

HUNTER, G. K .; HAUSCHKA, P. V.; POOLE, A. R.; ROSENBERG, L. C.; GOLDBERG, H. A. Nucleation and inhibition of hydroxyapatite formation by mineralized tissue proteins. Biochem. J., v. 317, p. 59-64, 1996.

HYNES, R. O.; YAMADA, K. M. Fibronectins: multifuncional modular glycoproteins. J. Cell Biol., v. 95, p. 369-377, 1982.

IBA, K.; SAWADA, N.; CHIBA, H.; HIDEKI, C.; WEWER, U. M.; ISHII, M. M. Tansforming growth factor- $\beta 1$ downregulates dexamethasone-induced tretanectin gene expression during the in vitro mineralization of the human osteoblastic cell line SV-HFO. FEBS Lett., v. 373, p. 1-4, 1995. 
IBA, K.; SAWADA, N.; NUKA, S.; CHIBA, H. OBATA, H.; ISOMURA, H.; SATOH, M.; ISHII, S.; MORI, M. Phase-dependent effects of transforming growth factor $\beta 1$ on osteoblast markers of human osteoblastic cells line SV-HFO during mineralization. Bone, v. 19, p. 363, 1996.

ISHIDA, Y.; HEERSCHE, J. N. Progesterone stimulates proliferation and differentiation of osteoprogenitor cells in bone cell populations derived from adult female but not from adult male rats. Bone, v. 20, p. 17-25, 1997.

ISHIDA, Y.; HEERSCHE, J. N. Glucocorticoid-induced osteoporosis: both in vivo and in vitro concentrations of glucocorticoids higher than physiological levels attenuate osteoblast differentiation. J. Bone Miner. Res., v. 13, p. 1822-1826, 1998.

JILKA, R. L.; WEINSTEIN, R. S.; BELLILDO, T.; PARFITT, A. M.; MANOLAGAS, S. C. Osteoblast programmed cell death (apoptosis): modulation by growth factors and cytokines. JBMR, v. 13, p. 793-802, 1998.

KADLER, K. E.; HILL, A.; CANTY-LAIRD, E. G. Collagen fibrillogenesis: fibronectin, integrins, and minor collagens as organizers and nucleators. Curr. Opin. Cell Biol., v. 20, p. 495-501, 2008.

KASUGAI, S.; ADACHI, M.; OGURA, H. Establishment and characterization of a clonal cell line (RPC-C2A) from dental pulp of the rat incisor. Arch. Oral Biol., New York, v. 33, p. 887-91, 1988.

KATCHBURIAN, E.; ARANA-CHAVEZ, V.E. Histologia e Embriologia Oral. $2^{\mathrm{a}}$ ed. Rio de Janeiro: Guanabara Koogan-Panamericana, 2004.

KAZANECKI, C. C.; UZWIAK, D. J.; DENHARDT, D. T. Control of osteopontin signaling and function by post-translational phosphorylation and protein folding. $\mathbf{J}$. Cell Biochem., v. 102, p. 912-924, 2007.

KIM, K. K.; JI, C.; CHANG, W.; WELLS, R. G.; GUNDBERG, C. M.; McCARTHY, T. L.; CENTRELLA, M. Repetitive exposure to TGF-beta suppresses TGF-betal receptor expression by differentiated osteoblasts. Gene, v. 379, p. 175-184, 2006.

KINGSLEY, D.M. The TGF-beta superfamily: new members, new receptors and new genetic test of function in different organisms. Genes Dev., v. 8, p. 133-146, 1994.

KLOEN, P.; JENNINGS, C. L.; GEBHARDT, M. C.; SPRINGFIELD, D. S.; MANKIN, K. L. Expression of transforming growth factor-beta (TGF-beta) receptors, TGF-beta 1 and TGF-beta 2 production and autocrine growth control in osteosarcoma cells. Int. J. Cancer, v. 58, p. 440-445, 1994.

KUO, M.Y.; LAN, W.H.; LIN, S.K.; TSAI, K.S.; HAHN, L.J. Collagen gene expression in human dental pulp cell cultures. Arch. Oral Biol., New York, v. 37, n. 11, p. 945952, 1992. 
LEISS, M.; BECKMANN, K.; GIRÓS, A.; COSTELL, M.; FÄSSLER, R. The role of integrin binding sites in fibronectin matrix assembly in vivo. Curr. Opin. Cell Biol., v. 20, p. 502-507, 2008.

LENER, U. H. Osteoclast formation and resorption. Matrix Biol., v. 19, p. 107-120, 2000.

LI, M.; AMIZUKA, N.; ODA, K.; TOKUNAGA, K.; ITO, T.; TAKEUCHI, K.; TAKAGI, R.; MAEDA, T. Histochemical evidence of the initial chondrogenesis and osteogenesis in the periosteum of a rib fractured model: implications of osteocyte involvement in periosteal chondrogenesis. Microsc. Res. Tech., v. 64, p. 330-342, 2004.

LIAW, L.; SKINNER, M. P.; RAINES, E. W.; CHERESH, D. A.; SCHAWARTZ, S. M.; GIACHELLI, C. M. The adhesive and migratory effects of osteopontin are mediated via distinct cell surface integrins. Roles of alpha $v$ beta 3 in smooth muscle cell migration to ostopontin in vitro. J. Clin. Invest., v. 95, p. 713-724, 1995.

LIEB, E.; VOGEL, T.; MILZ, S.; DAUNER, M.; SCHULZ, M. B. Effects of transforming growth factor $\beta 1$ on bonelike tissue formation in three-dimensional cell culture. II. Osteoblastic differentiation. Tissue Eng., v. 10, 1414-1425, 2004.

LUO, X. H.; LIAO, E. Y.; SU, X. Progesterone upregulates TGF-b isoforms (b1, b2 e b3) expression in normal human osteoblast-like cells. Calcif. Tissue Int., v. 71, p. 329-334, 2002.

MACDOUGALL, M.; SIMMONS, D.; LUAN, X.; NYDEGGER, J.; FENG, J.; GU, T. T. Dentin phosphoprotein and dentin sialoprotein are cleavage products expressed from transcript coded by a gene on human chromosome4. Dentin phosphoprotein DNA sequence determination. J. Biol. Chem., v. 272, p. 835-842, 1997.

MAEGAWA, N.; KAWAMURA, K.; HIROSE, M.; YAJIMA, H.; TAKAKURA, Y.; $\mathrm{OHGUSHI}, \mathrm{H}$. Enhancement of osteoblastic differentiation of mesenchymal stromal cells cultured by selective combination of bone morphogenetic protein-2 (BMP-2) and fibroblast growth factor-2 (FGF-2). J. Tissue Eng. Regen. Med., v. 4, p. 306-313, 2007.

MALAVAL, L.; LIU, F.; ROCHE, P.; AUBIN, J. E. Kinetics of osteoprogenitor proliferation and osteoblast differentiation in vitro. J. Cell Biochem., v. 74, p. 616627, 1999.

MANOLAGAS, S. C, Birth and death of bone cells: basic regulatory mechanisms and implications for pathogenesis and treatment of osteoporosis. Endocrinol. Rev., v.21, p. 115-137, 2000.

MARTINEZ, E. F.; ARAUJO, V. C; SOUSA, S. O. M.; ARANA-CHAVEZ, V. E. TGFbeta1 enhances the expression of alpha-smooth muscle actin in cultured human 
pupal fibroblasts: immunochemical and ultrastructural analyses. J. Endod., v. 33, p. 1313-1318, 2007.

MASSA, L. F.; ARANA-CHAVEZ, V. E. Ultrastructural preservation of rat embryonic dental tissues after rapid fixation and dehydration under microwave irradiation. Eur. J. Oral Sci., v. 108, n. 1, p. 74-77, 2001.

MASSAGUÉ, J. How cells read TGF-beta signals. Nat. Rev. Mol. Cell Biol., v. 1, p. 169-178, 2000.

McKEE, M. D.; NANCI, A. Osteopontin and the bone remodeling sequence. Colloidal-gold immunocytochemistry of an interfacial extracellular matrix protein. Ann. N. Y. Acad. Sci., v. 760, p. 177-189, 1995.

McKEE, M. D.; NANCI, A. Osteopontin: an interfacial extracellular matrix protein in mineralized tissues. Connect. Tissue Res., v. 35, p. 197-205, 1996.

MOURSI, A. M.; DAMSKY, C. H.; LULL, J.; ZIMMEMAN, D.; DOTY, S. B.; AOTA, S.; GLOBUS, R. K. Fibronectin regulates calvarial osteoblast differentiation. J. Cell Sci., v. 109, p.1369-1380, 1996.

MOURSI, A. M.; GLOBUS, R. K.; DAMSKY, C. H. Interactions between integrin receptors and fibronectin are required for calvarial osteoblast differentiation in vitro. J. Cell Sci., v.110, p. 2187-2196, 1997.

NAKASHIMA, M. Establishment of primary cultures of pulp cells from bovine permanent incisors. Arch. Oral Biol., New York, v. 36, n. 9, p. 655-63, 1991.

$\mathrm{NANCI}, \mathrm{A}$. Content and distribution of noncollagenous matrix proteins in bone and cementrum: relationship to speed of formation and collagen packing density. $\mathbf{J}$. Struct. Biol., v. 126, p. 256-269, 1999.

NANCI, A.; WAZEN, R. M.; ZALZAL, S. F.; FORTIN, M.; GOLDBERG, H. A.; HUNTER, G. K.; GHITESCU, D-L. A tracer study with systemically and locally administered dinitrophenylated osteopontin. J. Histochem. Cytochem., v. 52, p. 1591-1600, 2004.

NEFUSSI, J. R.; BOY-LEFEVRE, M. L.; BOULEKBACHE, H.; FOREST N. Mineralization in vitro of matrix formed by osteoblasts isolated by collagenase digestion. Differentiation, v. 29, p. 160-168, 1985.

NOBLE, B. S; STEVENS, H.; LOVERIDGE, N; REEVE, J. Identification of apoptotic changes in osteocytes in nomal and pathological human bone. Bone, v. 20, p. 73282, 1997.

NODA, M. Cellular and molecular biology of bone. San Diego: Academic Press, 1993. 
NORDAHL, J.; MENGARELLI-WIDHOLM, D.; HULTENBY, K.; REINHOLT, F. Ultrastructural immunolocalization of fibronectin in epiphyscal and metaphysical bone of young rats. Calcif. Tissue Int., v. 57, p. 2187-2196, 1995.

OGATA, Y. Bone sialoprotein and its transcriptional regulary mechanism. J. Periodont. Rev., v.43, p. 127-135, 2008.

OWEN, T. A.; ARONOW, M.; SHALHOUB, V.; BARONE, L. M.; WILMING, L.; TASSINARI, M. S. et al. Progressive development of the rat osteoblast phenotype in vitro: Reciprocal relationships in expression of genes associated with osteoblast proliferantion and differentiation during formation of the bone extracellular matrix. $\mathbf{J}$. Cell Physiol., v. 143, p. 420-430, 1990.

PÉCHEUR, I.; PEYRUCHAUD, O.; SERRE, C. M.; GUGLIELMI, J.; VOLAND, C.; BOURRE, F.; MARGUE, C.; COHEN-SOLAL, M.; BUFFET, A.; KIEFFER, N.; CLÉZARDIN, P. Integrin alpha $(\mathrm{v})$ beta 3 expression confers on tumor cells a greater propensity to metastasize to bone. FASEB J., v. 16, p. 1266-1268, 2002.

PURPURA, K. A.; AUBIN, J. E.; ZANDSTRA, P. W. Sustained in vitro expansion of bone progenitors is cell density dependent. Stem Cells, v. 22, p. 39-50, 2004.

QUIN, C.; BABA, O.; BUTLER, W. T. Post-translational modifications of SIBLING proteins and theirs roles in osteogenesis and dentinogenesis. Crit. Rev. Oral Biol. Med., v. 15, p. 126-136, 2004.

RAZZOUK, S.; BRUNN, J. C.; QIN, C.; TVE, C. E.; GOLDBERG, H. A.; BUTLER, W. T. Osteopontin posttranslational modifications, possibly phosphorylation, are required for in vitro bone resorption but not osteoclast adhesion. Bone, v. 30; p. 40-47, 2002.

REDDI, A.H.; SULLIVAN, N.E. Matrix-induced endochondral bone differentiation: influence of hypophysectomy, growth hormone, and thyroid-stimulating hormone. Endocrinology, v. 107, p. 1291-1299, 1980.

REINHOLT, F. P.; HULTENBY, K.; OLDBERG, A.; HEINEGARD, D. Osteopontin - a possible anchor of osteoclasts to bone. Proc. Nadl. Acad. Sci. USA., v. 87, p. 44734475, 1990.

ROBERTS, A. B.; SPORN, M. B. Peptide growth factors and their receptors. Growth Factors, v. 8, p. 1-9, 1990.

ROBERTS, C.J.; BIRKENMEIER, T.M.; McQUILLAN, J.J.; AKIYAMA, S.K., YAMADA, S.S.; CHEN, W.T.; YAMADA, K.M.; McDONALD, J.A. Transforming growth factor beta stimulates the expression of fibronectin and of both subunits of the human fibronectin receptor by cultured human lung fibroblasts. J. Biol. Chem., v. 263, p. 4586-4592, 1988.

RODAN, G. A.; NODA, M. Gene expression in osteoblast cells. Crit. Rev. Eukaryot Gene Expr., v. 1, p. 85-98, 1991. 
SHALHOUB, V.; CONLON, D.; TASSINARI, M.; QUINN, C.; PARTRIDGE, N. ; STEIN, G. S. ; LIAN, J. B. Glucocorticoids promote development of the osteoblast phenotype by selectively modulating expression of cell growth and differentiation associated genes. J. Cell Biochem., v. 50, p. 425-440, 1992.

SHAPIRO, H. S.; CHEN, J.; WRANA, J. L.; ZHANG, Q.; BLUM, M.; SODEK, J. Characterization of porcine bone sialoprotein: primary structure and cellular expression. Matrix, v. 13, p. 431-440, 1993.

SHEN, Z-J; KIM, S. K.; KWON, O-S; YOUNG, S. L.; MOON B. J. Specific inhibition of transforming growth factor- $\beta 2$ expression in human osteoblast cell by antisense phophorothioate oligonucleotides. Eur. J. Biochem., v. 268, p. 2331-2337, 2001.

SHI, Y.; MASSAGUÉ, J. Mechanisms of TGF- $\beta$ signaling from cell membrane to the nucleus. Cell, v. 113, p. 685-700, 2003.

SODEK, J.; CHEN, J.; NAGATA, T.; KASUGAI, S.; TODESCAN, R. Jr. et al. Regulation of osteopontin expression in osteoblasts. Ann. N. Y. Acad. Sci., v. 760, p. 223-241, 1995.

SODEK, J.; GANSS, B.; McKEE, M. D. Osteopontin. Crit. Rev. Oral Biol. Med., v. 11 , p. 279-303, 2000.

SODEK, J.; McKEE, M. D. Molecular and cellular biology of alveolar bone. Periodontol. 2000, v. 24, p. 99-126, 2000.

STANDAL, T.; BORSET, M.; SUDAN, A. Role of osteopontin in adhesion, migration, cell, survival and bone remodeling. Exp. Oncol., v. 26, p. 179-184, 2004a.

STANDAL, T; HJORTH-HANSEN, H.; RASMUSSEN, T.; DAHL, I. M.; LENHOFF, S.; BRENNE, A. T.; SEIDEL, C.; BAYKOV, V.; WAAGE, A.; BORSET, M.; SUNDAN, A.; HJERTNER, O. Osteopontin is an adhesive factor for myeloma cells and is found in increased levels in plasma from patients with multiple myeloma. Haematologica, $v$. 89, p. 174-182, 2004b.

STEIN, G. S.; LIAN, J. B. Molecular mechanisms mediating proliferation/differentiation interrelationships during progressive development of osteoblast phenotype. Endocr. Rev., v. 14, p. 424-442, 1993.

STEIN, G. S.; LIAN, J. B.; OWEN, T. A. Relationship of cell growth to the regulation of tissue-specific gene expression during osteoblast differentiation. FASEB J., v. 4; p. 3111-3123, 1990.

STEITZ, S. A.; SPEER, M. Y., McKEE, M. D., LIAW, L.; ALMEIDA, M.; YANG, H.; GIACHELLI, C. M. Osteopontin inhibits mineral deposition and promotes regression of ectopic calcification. Am. J. Pathol., v. 161, p. 2035-2046, 2002. 
TAIRA, M.; NAKAO, H.; TAKAHASHI, J.; ARAKI, Y. Effects of two vitamins, two growth factors and dexamethasone on the proliferation of bone marrow stromal cells and osteoblastic MC3T3-E1 cells. J. Oral Rehabil., v. 30, p. 697-701, 2003.

TETI, A. Regulation of cellular functions by extracellular matrix. J. Am. Soc. Nephrol., p.S83-87, 1992, Suppl. 10.

TOYONO, T.; NAKASHIMA, M.; KUHARA, S.; AKAMINE, A. Expression of TGFbeta superfamily receptors in dental pulp. J. Dent. Res., v. 76, p. 1555-1560, 1997.

TURKSEN, K.; AUBIN, J. E. Positive and negative immunoselection for enrichrment of two classes of osteoprogenitor cells. J. Cell Biol., v. 114, p. 373-384, 1991.

YAMADA, K. M.; AOTA, S.; AKIYAMA, S. K.; LaFLAMME, S. E. Mechanisms of fibronectin and integrin function during cell adhesion and migration. Cold Spring Harb. Symp. Quant. Biol., v. 57, p. 203-212, 1992.

YAMAMOTO, N.; KAZUYUKI F.; HANADA K. Progressive development of the osteoblast phenotype during differentiation of osteoprogenitor cells derived from fetal rat calvaria: model for in vitro bone formation. Biol. Pharm. Bull., v. 25, p. 509-515, 2002.

YUN, S. I.; YOON, H. Y.; JEONG, S. Y.; CHUNG, Y. S. Glucocorticoid induces apoptosis of osteoblast cells through the activation of glycogen synthase kinase 3beta. J. Bone Miner. Metab., v. 27, p. 140-148, 2009.

ZOHAR, R.; CHEIFETZ, S.; McCULLOCH, C. A.; SODEK, J. Analysis of intracellular osteopontin as a marker of osteoblastic cell differentiation and mesenchymal cell migration. Eur. J. Oral Sci., v. 106, p. 401-407, 1998.

WADA, Y.; KATAOKA, H.; YOKOSE, S.; ISHIZUYA, T.; MIYAZONO, K.; GAO, Y.-H.; SHIBASAKI, Y.; YAMAGUCHI, A. Changes in osteoblast phenotype during differentiation of enzymatically isolated rat calvaria cells. Bone, v. 22, p. 479-485, 1998.

WEINSTEIN, S. P.; WILSON, C. M.; PRITSKER, A.; CUSHMAN, S. W. Dexamethasone inhibits insulin-stimulated recruitment of Glut4 to the cell surface in rat skeletal muscle. Metabolism, v. 47, p. 3-6, 1998.

WINNARD, R. G.; GERSTENFELD, L. C.; TOMA, C. D.; FRANCESCHI, R. T. Fibronectin gene expression, synthesis and accumulation during in vitro differentiation of chicken osteoblasts. J. Bone Miner. Res., v. 10, p. 1969-1977, 1995. 